DIW BERLIN

Discussion Papers

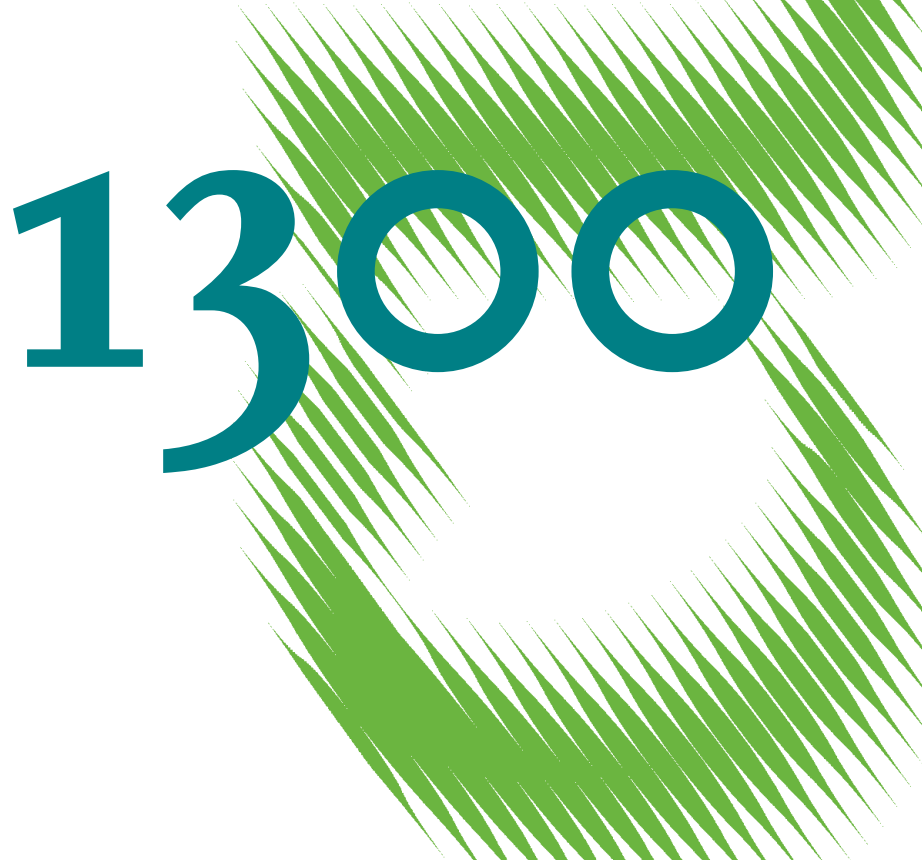

Measuring Alpha in the Fund Management Industry

Do Female Managers Perform Better? 
Opinions expressed in this paper are those of the author(s) and do not necessarily reflect views of the institute.

IMPRESSUM

(C) DIW Berlin, 2013

DIW Berlin

German Institute for Economic Research

Mohrenstr. 58

10117 Berlin

Tel. $+49(30) 89789-0$

Fax +49 (30) $89789-200$

http://www.diw.de

ISSN print edition $1433-0210$

ISSN electronic edition 1619-4535

Papers can be downloaded free of charge from the DIW Berlin website:

http://www.diw.de/discussionpapers

Discussion Papers of DIW Berlin are indexed in RePEc and SSRN:

http://ideas.repec.org/s/diw/diwwpp.html

http://www.ssrn.com/link/DIW-Berlin-German-Inst-Econ-Res.html 


\title{
Measuring Alpha in the Fund Management Industry: Do Female Managers Perform Better?
}

\author{
Vassilis Babalos ${ }^{1}$, Guglielmo Maria Caporale ${ }^{2^{*}}$, Nikolaos Philippas ${ }^{3}$ \\ ${ }^{1}$ Department of Finance and Auditing, School of Management and Economics, Technological \\ Educational Institute of Kalamata, Greece \\ ${ }^{2}$ Department of Economics and Finance, Brunel University, London, UK \\ ${ }^{3}$ Department of Business Administration, University of Piraeus, Greece
}

\begin{abstract}
This paper examines the performance of 358 European diversified equity mutual funds controlling for gender differences. Fund performance is evaluated against funds' designated market indices and representative style portfolios. Consistently with previous studies, no significant differences in performance and risk are found between female and male managed funds. However, perverse market timing manifests itself mainly in female managed funds and in the left tail of the returns distribution. Interestingly, at fund level there is evidence of significant overperformance that survives even after accounting for funds' exposure to known risk factors. Employing a quantile regression approach reveals that fund performance is highly dependent on the selection of the specific quantile of the returns distribution; also, style consistency for male and female managers manifests itself across different quantiles. These results have important implications for fund management companies and for retail investors' asset allocation strategies.
\end{abstract}

JEL Classification: G11,G23

Keywords: Mutual funds, performance, timing, gender difference, quantile regression

\footnotetext{
${ }^{*}$ Corresponding author. Research Professor at DIW Berlin.

E-mail: Guglielmo-Maria.Caporale@brunel.ac.uk
} 



\section{Introduction}

Since their launch towards the end of the $19^{\text {th }}$ century mutual funds have been acting as financial intermediaries channelling savings to the most profitable investments, thereby promoting financial stability and social welfare. Designed to provide liquidity, they are the preferred investment vehicle for retail investors mainly because of the benefits of risk diversification and professional management that are not otherwise easily accessible. Mutual funds' shareholders benefit when fund managers search for the most attractive investments, which in turn results in maximization of the shareholders' expected return. However, it is not so rare for fund managers to act in a self-interested manner seeking to maximize their compensation through the adoption of gambling strategies (Chevallier \& Ellison 1997). A fundamental question that naturally arises is whether active fund managers add value to their portfolios. Their ability to enhance portfolio returns is measured by the so-called alpha (Jensen 1968). The search for a reliable estimate of alpha in the delegated active management industry still continues.

Following the seminal work of Treynor (1965), Sharpe (1966) \& Jensen (1968) most papers have been striving to determine whether actively managed funds are able to deliver superior risk-adjusted returns with respect to a benchmark portfolio. Traditional performance measures compare the return of the portfolio of interest with that of a properly defined unmanaged portfolio (benchmark return) after accounting for all aspects of investment risk. The evolution of financial theory has contributed substantially to the proper definition of systematic risk sources that should be accounted for when evaluating the performance of active fund managers. In this context, the single factor evaluation model introduced by Jensen (1968) has been replaced by multi-factor models (Fama \& French 1993, Carhart 1997) motivated mainly by asset pricing studies and others that stress the importance of incorporating economic indicators in predicting future market movements (Ferson \& Schadt 1996, Kosowski, 2006, Jha et al., 2009). Their main finding is that actively managed funds do not systematically generate higher returns than a passive benchmark on a risk adjusted basis after deducting various expenses and charges (Fama \& French 2010). 
In the last fifty years the mutual fund industry has been the subject of extensive research both by academics and practitioners. Sirri \& Tufano (1998) in their influential study pointed out the importance of mutual funds as a laboratory where one can study the actions of retail investors who buy fund shares. Investors usually base their selection on past performance information but invest asymmetrically, i.e. more in funds that performed very well in the near past. It is generally agreed that actively managed mutual funds, on average, fail to outperform the market or any combination of passively managed portfolios. However, there is evidence that some predetermined variables such as past performance have predictive power for future investment performance. Performance either measured in an absolute way or on a risk-adjusted basis is related to past performance, managerial characteristics including manager age, education etc. (Chevallier \& Ellison 1999) and fund characteristics such as expenses, turnover and size (Prather et al, 2004); investors seem to recognize this to a certain extent and chase past winners (Gruber 1996). Similarly, funds that attract more money subsequently perform significantly better than those that lose money. This effect, known as smart money effect, is short-lived and is largely but not completely explained by a strategy of betting on winners (Gruber 1996, Zheng 1999).

Our study is strongly related to the research conducted in other disciplines such as psychology or game theory. The reason is that fund performance evaluation should explicitly allow for the behavioural dimension of managers' decision making. In particular, well documented differences between men and women in terms of investment behaviour and/or risk-taking that have attracted the research interest of other social sciences and economics literature should be addressed. For example, previous studies have shown that men are more confident (Barber \& Odean 2001) and/or less risk averse than women (Sunden \& Surette 1998). However, the latter was disputed by Schubert et al. (1999), who attributed women's higher levels of risk aversion to the use of survey data and their inability to capture adequately differences in other relevant factors such as the investment opportunity set. Professional money management provides the perfect setting to explore stereotyped behavioural issues mainly because it includes a homogeneous group of individuals with comparable levels of financial expertise. It allows to capture differences in wealth and knowledge in a more effective manner than in an experimental setting. Both Atkinson et al. 
(2003) and Niessen \& Ruenzi (2007), using a sample of US bond and equity funds respectively, reached the conclusion that there are no significant differences in the risk-adjusted performance of male and female managers. In a related study Beckmann \& Menhoff (2008) analyzed the survey responses of 649 fund managers in the US, Germany, Italy and Thailand and confirmed that female fund managers are more risk averse and less overconfident than men.

The present paper contributes to the mutual fund performance literature in several ways. First, we compare the performance of male and female managed equity funds employing a large sample of European diversified equity funds which includes one of the largest proportions of female professionals in studies in this field. Second, for the first time in the literature we compare the ability of managers to predict not only market portfolio returns but also the size and growth of portfolios. To this end, we apply the approach of Treynor \& Mazuy (1966) to the multi-factor Fama \& French model (1996) in the spirit of Lu (2005). Third, we control for differences in style since funds are classified into fourteen investment categories and their performance is measured against a proper benchmark for each category. This ensures that we mitigate any of the biases related to inappropriate benchmarking that have been thoroughly examined by Lehmann \& Modest 1987, Elton et al. 1993, and Sensoy 2009 inter alia. Fourth, owing to the considerable heterogeneity in returns both at fund and portfolio level we employ a quantile approach to explore fund performance and style consistency across various pre-specified regions of the returns distribution. Finally, we address the need highlighted by Banegas et al. (2013) for a more comprehensive research on European funds and especially for funds that invest across Europe. ${ }^{\dagger}$

To preview our results, we find that gender does not influence fund performance and that women are not more risk averse than men. However, at fund level we detect statistically and economically significant alphas, mainly in the Eurozone Large Cap investment category. The documented over-performance of many individual funds becomes particularly important in the light of the turbulence experienced by financial markets resulting from the global financial crisis and the ensuing Eurozone debt crisis. In terms of market timing we document that women are worse market timers than men. In particular, half of women in our sample exhibit perverse market timing.

\footnotetext{
${ }^{\dagger}$ A widely known study that examines more than one European fund market is that by Otten and Bams (2002).
} 
Although female managers are in charge of larger funds and shareholders in female managed funds pay on average lower management fees, these differences are not significant. The only significant difference is found in the purchase fee that is substantially higher for male managed funds. However, one should bear in mind that purchase and sales fees are usually determined by a management company's sales policy and therefore any differences should be interpreted with caution. We also observe a marginally significant difference in the trading behaviour of the managers in the sample, a finding that points explicitly to the overconfidence hypothesis (Barber \& Odean 2001) and requires further research. With respect to portfolio quality, both female and male managed funds appear to be sufficiently diversified. As for investment strategies, male managers seem to favour small size stocks whereas female managers prefer more growth-oriented strategies. The estimation of fund performance employing the quantile regression method provides more insights into the fund management process as we move from the left to the right of the conditional returns distribution. Performance appears to be highly dependent on the selection of a specific quantile of the returns distribution. Perverse market timing is still present and more intense in the left tail of the distribution. Finally, there is decreasing market exposure as one moves to the right of the returns distribution irrespective of the gender.

The remainder of the paper is organised as follows. The next section outlines the data selection process while section 3 describes the employed performance models and the robust quantile regression approach. The empirical results are presented in section 4 and section 5 concludes.

\section{Mutual funds data}

We collect monthly returns of European diversified equity mutual funds with a European equity investment focus that are domiciled in one of the four largest European fund markets, namely France, Germany, Italy and Spain ${ }^{\ddagger}$. The data source is the Morningstar Direct comprehensive database covering the period from January 2006 to December 2011. Mutual fund returns are calculated by computing the change in monthly net asset value (NAV), reinvesting all income and capital gains during the

\footnotetext{
‡ Except for the fund markets of Luxembourg, Ireland and the United Kingdom.
} 
month, and dividing by the NAV at the beginning of the month. Returns are not adjusted for sales charges (such as front-end or deferred loads and redemption fees), since we are only concerned with fund manager's skills and investment strategy. Excess returns have been calculated with respect to the 3-month Euribor rate. Monthly prices of the relevant benchmark indices and the Euribor rate were obtained from Thomson Reuters (Datastream).

We apply a preliminary filter on all available funds offered in the four markets excluding funds that are team managed. Next, the gender of each fund manager is identified from the manager profile data. In this way we are able to gather data on fifty-nine female-managed mutual funds and two hundred and ninety-nine malemanaged funds as reported in the last row of Table 1. It should be noted that the proportion of females to total population in our study is larger than in most previous studies in this area of the literature. For example, Chevallier \& Ellison (1997) reported a 7\% share of women in their sample, in Atkinson et al. (2003) females constituted 5.6\% of the total sample, while Niessen \& Ruenzi (2007) performed their analysis with a share of female professionals of approximately $10 \%$. Only the survey response study of Beckmann \& Menkhoff (2008) has a 19\% share of female managers which is larger than ours. Sample funds are then classified into fourteen different categories on the basis of their investment objective. Following Golec (1996), who concluded that manager tenure is associated with future fund performance, we match tenure to fund performance in order to ensure comparability of funds' realized performance. Index funds and exchange traded funds are both excluded since we are interested in active management.

\section{-Insert Table 1 here-}

Table 2 reports some useful statistics for male and female managed equity funds. Average values for both groups as well as the statistical significance of the difference between the female and male managed equity funds are presented. It appears that there are only minor differences. The only significant one is observed in the column max front load. Investors preferring a male managed fund are faced with a substantially higher sales fee than if they had invested in a female managed fund. Moreover, the turnover ratio is substantially different in the two samples, although the 
difference is only marginally significant. This finding could be explained by the argument of Barber \& Odean (2001), who claimed that overconfident investors such as male investors might engage into more frequent trading, which is confirmed in our case by the substantially higher turnover ratio for male managers. Finally, female managers are in charge of larger funds while shareholders in female managed funds pay lower management fees. The latter might be due to behavioural factors in professional money management. As stated previously, male managers might have more confidence in their management skills, which leads them to claim higher compensation than female managers.

Table 3 presents some descriptive statistics for the employed series. The last column implies non-normality of the returns of male and female managed portfolios across the majority of investment styles. This is an important finding that motivates the use of the more robust quantile regression method as a tool for exploring the behaviour of the conditional returns distribution. A comparison of the two portfolios in terms of the median return and variability of returns provides some preliminary evidence on the performance of male and female managers. In particular, in general there are no statistically significant ${ }^{\S}$ differences either in the average return or in the total riskiness of the two portfolios. The latter sheds light on managers' attitude towards risk, allowing us to conclude that male and female managers exhibit similar risk appetite as in Atkinson et al. (2003). For better comparisons a synthetic portfolio that goes long in male managers and simultaneously short in female managers has been constructed and monitored across the various investment categories. Return statistics of the synthetic portfolio are reported in the row labelled Male vs. Female. Interestingly, we do not detect any evidence of significant over- or under- portfolio performance, which reinforces the evidence that male and female managers perform similarly.

-Insert Table 2 here-

-Insert Table 3 here-

\footnotetext{
$\S$ For the comparison of the portfolio medians we have employed the Wilcoxon/Mann-Whitney nonparametric test while an F-test has been carried out for the variance comparison.
} 


\section{Methodology}

Accurate performance evaluation is crucial in the fund management industry. There is an ongoing debate in the literature on whether mutual fund managers should be evaluated against the benchmark reported in their prospectus or with respect to a broad market-based passive portfolio of comparable risk (see, inter alia, Cremers and Petajisto, 2009, Sensoy, 2009, Hsu et al., 2010, Cremers, et al., 2010, Angelidis et al. 2012). Benchmark mismatches may result in severe misconceptions regarding funds' risk exposures or funds' superior skills at generating abnormal returns. In the context of the present study, we address this issue by relying on the benchmarks officially assigned by Morningstar to each fund category, which are presented in Table 4.

\section{-Insert Table 4 here-}

\subsection{Security selection models}

\subsubsection{Single factor model}

The first performance measure employed here is the well-known Jensen's alpha (1968), that is rooted in the CAPM theory. It measures the additional return generated by a fund over and above that justified by market risk, thereby conveying information on security selection or selectivity skills of a fund manager. Formally, the single factor performance measure is the intercept $\left(\alpha_{p}\right)$ in the regression of the fund excess returns on the excess returns of a representative market index:

$$
R_{p, t}-R_{f, t}=\alpha_{p}+\beta_{p, 1}\left(R_{m, t}-R_{f, t}\right)+\varepsilon_{p, t}
$$

where $R_{p, t}$ is the return of fund $p$ in period $t ; R_{f, t}$ is the short term risk-free rate in period $t ; R_{m, t}$ is the return of the proper market portfolio of each fund in period $t$.

\subsubsection{Multi-factor model}

We then employ a modified version of the Fama \& French (1993) three factor model. In particular, we follow Elton et al. (1996, 1999), who used an overall market index, a size index and a growth versus value index that are readily available to investors via 
passive investment products such as index funds or exchange traded funds. This allows for direct comparisons of active fund managers with comparable passive strategies. Specifically, we opt for a multi-factor performance evaluation model that includes the STOXX Size and Style Indices tracking equity investments in Europe and the Eurozone respectively. We also employ the Barclays Corporate \& Government Total Return fixed income index in order to account for European funds' non-stock holdings. Fund overperfomance (underperformance) manifests itself as a significantly positive (negative) intercept $\left(\alpha_{p}\right)$ in the four-factor model that compares the realized returns of the fund against the returns of risk-bearing, passive investment strategies as follows:

$$
R_{p, t}-R_{f, t}=\alpha_{p}+\beta_{p, 1}\left(R_{m, t}-R_{f, t}\right)+\beta_{p, 2} S M B_{t}+\beta_{p, 3} H M L_{t}+\beta_{p, 4}\left(R_{B, t}-R_{f, t}\right)+\varepsilon_{p, t}
$$

where $\beta_{\mathrm{p}, 1}, \beta_{\mathrm{p}, 2}, \beta_{\mathrm{p}, 3}$ and $\beta_{\mathrm{p}, 4}$ are funds' exposures to the relevant risk factors; $\mathrm{R}_{\mathrm{p}, \mathrm{t}}$ is the return of fund $p$ in period $t$; $R_{f, t}$ is the short term risk-free rate in period $t ; R_{m, t}$ is the return of the proper market portfolio of each fund in period t; SMB (Small minus Big) stands for the returns of a size strategy and is constructed as the difference between the returns of the STOXX Europe Total Market Small Index and those of the STOXX Europe Total Market Large Index; HML (High minus Low) stands for the returns of the STOXX Europe Total Market Value Index minus those of the STOXX Europe Total Market Growth Index, and $\mathrm{R}_{\mathrm{B}, \mathrm{t}}$ is the return of the comprehensive fixed income index.

For funds investing mainly in the Eurozone we modify the benchmark portfolios accordingly, i.e. SMB is computed by taking the difference between the returns of the EURO STOXX Total Market Small Index and those of the EURO STOXX Total Market Large Index, while the HML benchmark factor is calculated as the difference between the returns of the EURO STOXX Total Market Value Index and those of the EURO STOXX Total Market Growth Index. 


\subsection{Factor timing models}

Market timing manifests itself as the ability of a fund manager to shift successfully its portfolio systematic risk in response to market movements. Traditional market timing models hypothesize that a skilled fund manager increases (decreases) its average market exposure when the market experiences positive (negative) returns, and therefore assume that fund returns are a convex function of benchmark returns in an attempt to quantify managers' timing skills. In the present study we employ the wellknown Treynor \& Mazuy (1966) (TM hereafter) model that assumes a time-varying market beta which in effect depends linearly on the market return. Therefore, market timing ability is captured by the coefficient $c_{p}$ in the non-linear regression of the TM model. Positive and significant values of $c_{p}$ indicate managers' successful market timing ability.

$$
R_{p, t}-R_{f, t}=\alpha_{p}+\beta_{p, 1}\left(R_{m, t}-R_{f, t}\right)+c_{p}\left(R_{m, t}-R_{f, t}\right)^{2}+\varepsilon_{p, t}
$$

The model above can be easily extended to include the benchmark portfolios of Fama \& French (1993) as well as two additional regressors that measure potential style timing in the spirit of Lu (2005), Benos et al. (2012) and Chen et al. (2013). In particular, we assume that the coefficients $\beta_{\mathrm{p}, 2}$ and $\beta_{\mathrm{p}, 3}$ of Eq. (2) are linearly related to the relevant benchmark returns, which yields the following factor timing model:

$$
\begin{aligned}
R_{p, t}-R_{f, t}= & \alpha_{p}+\beta_{p, 1}\left(R_{m, t}-R_{f, t}\right)+\beta_{p, 2} S M B_{t}+\beta_{p, 3} H M L_{t}+c_{p, 1}\left(R_{m, t}-R_{f, t}\right)^{2}+c_{p, 2} S M B^{2}{ }_{t} \\
& +c_{p, 3} H M L^{2}{ }_{t}+\varepsilon_{p, t}
\end{aligned}
$$

where $\mathrm{c}_{\mathrm{p}, 1} ; \mathrm{C}_{\mathrm{p}, 2} ; \mathrm{C}_{\mathrm{p}, 3}$ measure the ability of fund managers to time successfully the market, size and growth style respectively. Eq (4) enables us to disentangle more accurately the effect of each timing skill on fund performance.

\subsection{Quantile regression}

In this section we describe the quantile regression method proposed by Koenker and Bassett (1978) and Koenker (2005) employed here to explore the asymmetric 
behaviour of European fund returns. Quantile regression is a very robust tool in cases of non-symmetric distributions. It can provide extra information on the relationship between returns and the various risk factors, not only in the median return but across different, prespecified areas of the returns distribution. In particular, it overcomes the limitations of the traditional conditional-mean regression models and permits the estimation of various quantile functions, shedding light on the exposure of funds' returns to the various risk factors in the tails of the distribution. ${ }^{* *}$ Given that quantile analysis does not rely on any assumption with respect to the conditional distribution of funds' performance, it is particularly suited to our data with significant heterogeneity in returns.

The $\tau$-th conditional quantile function of a distribution is defined as:

$$
Q_{y_{i}}(\tau / x)=x_{i}^{T} \beta
$$

where $y_{i}$ is the dependent variable, in our case fund returns, $x_{i}$ is a vector of independent variables including various benchmark portfolio returns, and $\beta$ is a vector of risk loadings to be estimated. The estimator of $\hat{\beta}(\tau)$ is obtained by solving the following weighted minimization problem:

$$
\hat{\beta}(\tau)=\underset{\beta \in R^{p}}{\arg \min } \sum_{i=1}^{n} \rho_{\tau}\left(y_{i}-x_{i}^{T} \beta\right)
$$

where $\rho_{\tau}$ is a weighting function. For any $\tau \in(0,1)$ this takes the form:

$$
\rho_{\tau}\left(u_{i}\right)=\left\{\begin{array}{ll}
\tau u_{i} & \text { if } \mathrm{u}_{\mathrm{i}} \geq 0 \\
(\tau-1) u_{i} & \text { if } \mathrm{u}_{\mathrm{i}} \prec 0
\end{array} \quad \text { where } \mathrm{u}_{\mathrm{i}}=\mathrm{y}_{\mathrm{i}}-\mathrm{x}_{\mathrm{i}}^{\mathrm{T}} \beta\right.
$$

Combining equations (6) and (7) we get the following expression:

$$
\hat{\beta}(\tau)=\arg \min \left\{\sum_{i=1}^{n} \tau\left|y_{i}-x_{i}^{T}{ }^{T} y_{i} \geq x^{T} \beta\right|+\sum_{i=1}^{n}(1-\tau)\left|y_{i}-x_{i}^{T} \beta\right|\right\}
$$

\footnotetext{
Generally, each quantile regression defines a particular, centre or tail, point of a conditional distribution. This approach also allows the estimation of the median $\left(0.5^{\text {th }}\right.$ quantile) function as a special case, which can be thought of the mean function of the conditional distribution of funds' returns.
} 
Equation (8) shows that the quantile regression estimator is obtained by minimizing the weighted sum of the absolute errors, where the relative weights depend on the specified quantile.

\section{Results}

\subsection{Fund by fund analysis}

We first explore fund managers' skills in terms of selectivity and timing employing the entire fund universe described above. Tables 5 to 8 report the estimation results of Eq. (1)-(4) using the OLS method adjusted with the Newey-West (1987) procedure. We divide our dataset into male and female managers and according to the investment strategy adopted in order to capture potentially different skills. The results for the single factor model are reported in Table 5. Panel A reveals significant managerial talent for 120 funds while 9 appear to lack managerial skills. Panel B suggests that female managers are slightly superior to male managers in terms of performance. In particular, $37 \%$ of female managers have stock picking ability whereas almost 33\% of male managers achieve a higher risk-adjusted return. As for the distribution of significant single-factor alphas across investment styles, Panel C highlights overperformance for eight of the fourteen investment categories. The majority of significantly positive single-factor alphas are concentrated in the Eurozone LargeCap category.

However, the results for the more representative factor model reported in Table 7 provide a different performance picture. Specifically, Panel A shows that the number of funds with statistically significant positive alphas is slightly lower than according to the single factor model estimates (116 instead of 120) while the number of funds that underperform is higher (12 as opposed to 9). This finding is consistent with the vast literature suggesting that the omission of known risk factors that are priced in financial markets (Fama \& French 1993) can severely bias inference during the fund performance evaluation process, as well as with the results of Cuthbertson \& Nitzsche (2013) for the German market. Interestingly, Panel A of Table 8, where the estimated parameters of Eq. (2) are presented, indicates that almost half of the male managers have tilted towards small size stocks as revealed by their significant positive exposure 
to the SMB factor, whereas a substantial portion of female managers (36\%) favour a growth-oriented strategy. Again, the best performance is found for the funds belonging to the Eurozone Large-Cap category.

\section{-Insert Table 5 here-}

Market timing abilities of fund managers are investigated using the classical market timing model of Treynor \& Mazuy (1966). The results of the favourable and unfavourable values for the estimated parameters are reported in Table 6. Panel A shows that only a small number (13) of managers possess significant market timing abilities. Moreover, the gender analysis presented in Panel B shows that half of the female managers are poor market timers. By contrast, male managers dominate as successful market timers with twelve of the thirteen positive market timing coefficients. In terms of investment style, three fund styles, namely Europe Large-Cap Value, Europe Large-Cap Blend and Eurozone Large Cap, offer the strongest evidence of perverse market timing.

Next, we estimate an augmented Treynor \& Mazuy (1966) model to test for size and growth timing skills of fund managers in the spirit of $\mathrm{Lu}$ (2005). Three main points arise from Panel B of Table 8. First, we document substantial size and growth timing skills for European fund managers, which is consistent with the findings of $\mathrm{Lu}$ (2005). Second, male managers appear slightly superior to their female counterparts in terms of factor timing. Third, the results confirm that, as in the case of the simple TM model, female managers exhibit poor size and growth timing abilities: one out of five failed to adjust successfully her portfolio exposure to the growth factor.

\section{-Insert Table 6 here-}

-Insert Table 7 here- 


\section{-Insert Table 8 here-}

\subsection{Analysis at portfolio level}

In this section we repeat the analysis conducted above on two equally-weighted portfolios composed of male and female managers respectively. The results of the estimated single-factor model are presented in Table 9. We document statistically significant positive alphas in $\operatorname{six}^{\dagger+}$ out of the fourteen investment styles, the strongest performance being observed for the Italy Equity style. The aggregate results reinforce the earlier finding that female managers have an insignificant advantage over male managers: they are found to outperform their male counterparts in four (Europe Large-Cap Blend, Eurozone Large-Cap, France Large-Cap, Europe Large-Cap Value) out of the six investment styles that exhibit significant positive performance. With a few exceptions, male and female portfolios exhibit comparable exposures to market movements and sufficient levels of diversification as revealed by the values of the Adjusted $\mathrm{R}^{2} \mathrm{~s}$.

The results of the estimated four factor model are presented in Table 10. A few findings are noteworthy. First, this model explains the variability of fund returns better than the single factor one: the average adjusted $\mathrm{R}^{2}$ for the former across all investment categories is 0.94 compared to 0.92 for the latter. Although there are no significant differences across genders and models we document some substantial deviations for two styles (Europe Large Cap Growth, Spain Equity). Second, the estimated positive alphas are significantly lower. Examples include the France Large Cap category where the statistically significant coefficient for abnormal performance for male managers falls from $0.20 \%$ to $0.14 \%$. For female managers the adjustment in the documented performance resulting from the use of the multi factor model is not negligible and amounts to five basis points (0.05\%). Interestingly, German fund managers have adopted a positive and significant exposure to the corporate and sovereign bond market, in contrast to their fellow managers in the South (Italy Equity

\footnotetext{
${ }^{+}$The Eurozone Mid-Cap investment style is not included in the calculations owing to the absence of female managers in that category.
} 
\& Spain Equity). This finding may be related to the recent Eurozone debt crisis and the subsequent response of fixed income markets.

Table 11 reports the estimated coefficients of Eq. (3) for the two equally-weighted portfolios. Overall, the results at portfolio level confirm the poor market timing abilities documented earlier at fund level. In particular, perverse market timing characterizes both female and male managers for six of the fourteen investment styles, especially in the case of the former. For example, in the Europe Large-Cap Blend category the estimated negative value of the timing coefficient for female managers is twice as big as that for male managers and strongly significant (at the $1 \%$ significance level). Finally, Table 12 reports the estimated coefficients of Eq. (4) for the case of the two equally-weighted portfolios. The results indicate differences in timing behaviour for the two genders: there is weak evidence of size and growth timing ability of male managers for four investment categories (Eurozone Small Cap, Europe Mid-Cap, Europe Small Cap, France Small/Mid Cap), whilst female managers appear to have adopted a perverse growth timing strategy in the case of two investment styles (Europe Mid Cap, Europe Large-Cap Value).

\subsection{Quantile regression results}

Given the non-Gaussian nature of portfolio returns for male and female managers documented earlier we also investigate how the conditional dependence between fund returns and benchmark returns may vary across the entire range of their conditional distributions. Tables 13 and 14 report the estimation results for models (2) and (3) respectively employing the quantile regression approach. The multi-factor estimates of the alphas in the former are negative and statistically significant in the lower part of the conditional return distribution, i.e. for quantiles 0.05 and 0.25 , for all investment categories. On the other hand, they are positive and statistically significant in the right tail of the distribution. This implies that fund performance is highly dependent on the selection of a specific region of the returns distribution. Moreover, many investment styles (e.g. Eurozone Small Cap and Europe Large Cap-Value) are characterised by decreasing market exposure as one moves to the right of the returns distribution irrespective of the gender. This finding is consistent with those of Högholm et al. (2011) for 65 European large-cap mutual equity funds. Finally, the estimated exposures to the style benchmark indices across various quantiles allows us to draw 
conclusions regarding the style consistency of European fund managers. In particular, they suggest that they maintain the same exposure to known risk factors regardless of the return distribution area.

The quantile regression results of the TM model are reported in Table 14. The inference regarding market timing skills does not vary substantially compared to the OLS results. Both male and female managers exhibit negative timing skills concentrated mainly in the left tail of the returns distribution. Therefore, this approach provides the extra information that European fund managers lack market timing skills mostly in situations with low returns. Moreover, as in the OLS case, the majority of statistically significant negative coefficients is comparatively higher for female managers.

\section{Conclusions}

Fund managers' skills have been extensively investigated in the literature for almost five decades. In this study, using a large sample of European equity funds we have examined the possible effect of gender on the security selection and timing skills of active fund managers. Specifically, we have carried out a peer-group analysis based on fourteen investment categories in order to address some key issues in the active management evaluation process. Funds within each category have been evaluated against the relevant market benchmark index, thus ensuring more informative comparisons. In particular, we have employed the Fama \& French (1996) three-factor model augmented with a fixed-income securities index. Further, in the spirit of $\mathrm{Lu}$ (2005) we have followed the Treynor \& Mazuy (1966) timing approach to capture the potential size and growth timing skills of European fund managers. Our analysis has been conducted on a fund-by-fund basis and at the aggregate level.

Some preliminary evidence on funds' portfolio characteristics indicates that, although female managers are in charge of larger funds and shareholders in female managed funds pay on average lower management fees, these differences are insignificant. This also applies to the trading behaviour of the managers in our sample, a finding that can be interpreted in terms of the overconfidence hypothesis (Barber \& Odean 2001). 
As for gender analysis, we have documented the absence of significant differences in the performance of male and female fund managers. The multi-factor model estimates shed light on the security selection skills of fund managers. In particular, at fund level we detect statistically and economically significant alphas mainly in the Eurozone Large-Cap investment category. Female managers appear to be only slightly superior to their male counterparts in terms of their alphas but to possess perverse market timing skills. As for investment strategies, male managers seem to favour small size stocks whereas female managers prefer more growth-oriented strategies. Related to the above, there is weak evidence of positive size and growth timing for male managers whereas female managers generally fail to predict the movements of the growth factor.

Finally, given the skewness of the fund returns distributions we take a quantile regression approach to deal with the possible bias resulting from heterogeneity in returns. Fund performance indeed appears heavily sensitive to the choice of the distribution quantile, with the results being qualitatively the same for male and female managers, both categories displaying a persistent lack of market timing skills, especially for lower returns. 


\section{References}

Angelidis T., Giamouridis D., Tessaromatis N.,2013, Revisiting mutual fund performance evaluation, Journal of Banking \& Finance 37, 1759-1776

Atkinson S.M., Baird S.B., Frye M.B., 2003, Do female mutual fund managers manage differently?, The Journal of Financial Research 26, 1-18

Banegas A., Gillen B., Timmermann A., Wermers R., 2013, The cross section of conditional mutual fund performance in European stock markets , Forthcoming in the Journal of Financial Economics

Barber B.M., Odean T., 2001, Boys will be boys: Gender, overconfidence, and common stock investment, Quarterly Journal of Economics 116, 261-292

Beckmann D., Menkhoff L., 2008,Will Women Be Women? Analyzing the Gender Difference among Financial Experts, Kyklos 61, 364-384

Benos E., Jochec M., Nyekel V., 2010, Can mutual funds time risk factors?, The Quarterly Review of Economics and Finance 50, 509-514

Chen L.W, Adams A., Taffler R., 2013, What style-timing skills do mutual fund “stars” possess? Journal of Empirical Finance 21, pp. 156-173

Chevalier J., and Ellison G., 1997, "Risk taking by mutual funds as a response to incentives”, Journal of Political Economy 105,1167-1200

Chevallier, J. and Ellison G., 1999, “Are some mutual fund managers better than others? Cross-sectional patterns in behaviour and performance ”,Journal of Finance 54, 875-999

Cremers, K.J.M. and A. Petajisto, 2009, How active is your fund manager? A new measure that predicts performance, Review of Financial Studies 22, 3329-3365.

Cremers, M., A. Petajisto, and E. Zitzewitz, 2010, Should benchmark indices have alpha? Revisiting Performance Evaluation. Available at SSRN: http://ssrn.com/abstract=1108856.

Elton, E. Gruber M., Blake C., 1996, The persistence of risk-adjusted mutual fund performance, Journal of Business 69, 133-157 
Elton, E. Gruber M., Blake C., 1999, Common factors in active and passive portfolios, European Financial Review 3, 53-78

Fama, E. and K. French 1993, 'Common risk factors in the returns on bonds and stocks,' Journal of Financial Economics 33, 3-56.

Fama, E. F. and French, K. R., 1996, "Multifactor explanations of asset pricing anomalies”, Journal of Finance 51, 55-84

Fama E \& French K., 2010, "Luck versus Skill in the Cross Section of Mutual Fund Returns”, Journal of Finance 65, 1915-1947

Ferson, W. and Schadt R., 1996, "Measuring fund strategy and performance in changing economic conditions”, Journal of Finance 51, 425-461.

Gruber, M. J., 1996, “Another puzzle: The growth in actively managed mutual funds,” Journal of Finance 51, 783-810.

Högholm K., Knif J. , Pynnonen S., 2011, Fund Performance Robustness: An Evaluation Using European Large-Cap Equity Funds, Frontiers in Finance and Economics 8, 1-26

Hsu, J. C., V. Kalesnik, and B.W. Myers, 2010, Performance attribution: Measuring dynamic allocation skill, Financial Analysts Journal, 66, 6, 17-26.

Golec, J.H., 1996. The effects of mutual fund managers' characteristics on their portfolio performance, risk and fees. Financial Services Review 5, 133-148.

Jensen, M. C., 1968, The performance of mutual funds in the period 1945-1964, Journal of Finance 23: 389-416.

Jha, R., Korkie, B., Turtle, H. J., 2009. Measuring performance in a dynamic world: conditional mean-variance fundamentals. Journal of Banking and Finance 33, 18511859.

Koenker, R., 2005, Quantile Regression, Cambridge Books, Cambridge University Press, Cambridge.

Koenker, R. and Bassett Jr, G. 1978, Regression quantiles, Econometrica, 46, 33-50. 
Kosowski, R., 2006. Do mutual funds perform when it matters most to investors? Mutual fund performance and risk in recessions and expansions. Working paper, INSEAD.

Lehmann, B. N. \& Modest, D. M, 1987, Mutual fund performance evaluation: A comparison of benchmarks and benchmark comparisons, Journal of Finance 42, 233265

Lu, J., 2005, 'What is the Wind behind This Sail? Can fund managers successfully time their investment styles?’ Ph.D. Thesis (Cranfield School of Management).

Newey, W. K. and West, K. D., 1987, A simple, positive semi-definite, heteroskedasticity and autocorrelation consistent covariance matrix, Econometrica, 55, 703-8.

Niessen A., Ruenzi S., 2007, Sex Matters: Gender Differences in a Professional Setting, Working paper

Otten R., Bams D., 2002, “European mutual fund performance,” European Financial Management 8, 75-101.

Prather, L., Bertin W.J \& Henker T., 2004, “ Mutual fund characteristics, managerial attributes, and fund performance”, Review of Financial Economics 13, 305-326

Sensoy, B., 2009, Performance evaluation and self-designated benchmarks in the mutual fund industry, Journal of Financial Economics, 92, 25-39.

Sharpe, W. F. 1966, “Mutual fund performance”, Journal of Business 39, 119-138.

Sirri R., \& Tufano P., 1998, "Costly search and mutual fund flows”, Journal of Finance 53, 1589-1622

Sunden A. E., Surette B.J., 1998, Gender differences in the allocation of assets in retirement savings plans, American Economic Review 88, 207-211

Treynor, J. and K. Mazuy, 1966, 'Can mutual funds outguess the market?’ Harvard Business Review, 44, 131-36.

Treynor J., 1965, “How to rate management of Investment Funds;”, Harvard Business Review 43, 63-75. 
Zheng L., 1999, "Is money smart? A study of mutual fund investors' fund selection ability”, Journal of Finance 54, 901-933 


\section{APPENDIX}

Table 1

Female fund managers

\begin{tabular}{lcccc}
\hline \hline & & \multicolumn{3}{c}{$\begin{array}{c}\text { Number } \\
\text { of }\end{array}$} \\
Category & Male & Female & $\begin{array}{c}\text { Funds } \\
\text { Percentage } \\
\text { of female }\end{array}$ \\
\hline \hline Eurozone Small-Cap & 8 & 1 & 9 & $11.11 \%$ \\
Eurozone Mid-Cap & 9 & - & 9 & $0.00 \%$ \\
Eurozone Large-Cap & 78 & 18 & 96 & $18.75 \%$ \\
Europe Small-Cap & 2 & - & 2 & $0.00 \%$ \\
Europe Mid-Cap & 10 & 2 & 12 & $16.67 \%$ \\
Europe Large-Cap Value & 30 & 7 & 37 & $18.92 \%$ \\
Europe Large-Cap Growth & 2 & 4 & 6 & $66.67 \%$ \\
Europe Large-Cap Blend & 52 & 10 & 62 & $16.13 \%$ \\
France Large-Cap & 49 & 5 & 54 & $9.26 \%$ \\
France Small/Mid-Cap & 33 & 8 & 41 & $19.51 \%$ \\
Germany Large-Cap & 7 & - & 7 & $0.00 \%$ \\
Germany Small/Mid-Cap & 1 & - & 1 & $0.00 \%$ \\
Italy Equity & 4 & 1 & 5 & $20.00 \%$ \\
Spain Equity & 14 & 3 & 17 & $17.65 \%$ \\
\hline \hline Total & 299 & 59 & 358 & $16.48 \%$ \\
\hline \hline
\end{tabular}

Note: This table shows the allocation of funds that are managed by female managers as a percentage of the total funds by Morningstar investment category. Funds are classified by Morningstar into investment categories on the basis of the underlying portfolio holdings. 
Table 2

Funds’ operational \& cost variables

\begin{tabular}{||l|ccccccc||}
\hline & $\begin{array}{c}\text { Assets under } \\
\text { management } \\
\text { (millions } € \text { ) }\end{array}$ & $\begin{array}{c}\text { Age } \\
\text { (in years) }\end{array}$ & $\begin{array}{c}\text { Expense } \\
\text { ratio } \\
\mathbf{( \% )}\end{array}$ & $\begin{array}{c}\text { Turnover } \\
\text { ratio } \\
\mathbf{( \% )}\end{array}$ & $\begin{array}{c}\text { Management } \\
\text { Fee } \\
\mathbf{( \% )}\end{array}$ & $\begin{array}{c}\text { Max } \\
\text { front } \\
\text { load } \\
\mathbf{( \% )}\end{array}$ & $\begin{array}{c}\text { Morningstar } \\
\mathbf{5 - s t a r} \\
\text { ratings }\end{array}$ \\
\hline \hline Male & 93.80 & 12.91 & 2.10 & 120.57 & 1.42 & 2.95 & $\begin{array}{c}26 \text { out of } \\
288(9.03 \%)\end{array}$ \\
\hline \hline Female & 136.94 & 12.97 & 1.84 & 67.12 & 1.31 & 2.51 & $\begin{array}{c}5 \text { out of } 57 \\
(8.77 \%)\end{array}$ \\
\hline \hline -value & 0.15 & 0.95 & 0.18 & 0.11 & 0.26 & 0.06 & - \\
\hline \hline
\end{tabular}

Note: This table shows the average assets under management, age, expense ratio, turnover ratio, management fee, max front load and Morningstar 5-star ratings for male and female managed equity funds. Assets are expressed in millions of euros while fund age is measured in years. The expense ratio is the percentage of fund assets paid for operating expenses and management fees, including $12 \mathrm{~b}-1$ fees, administrative fees and all other asset-based costs incurred by the fund. Management fee is also reported in a separate column. Turnover ratio measures trading activity of the portfolio manager and is computed as the lesser of purchases or sales divided by average monthly assets. Max front load denotes the max of the purchase fees deducted from the amount of the investment. The Morningstar 5-star rating denotes funds that receive the highest ranking among their peer group according to Morningstar risk-return analysis. The p-value indicates the significance of the difference between the sample means. Data are from Morningstar as of December 2011.

Table 3

Summary statistics for European equity funds and their benchmarks

\begin{tabular}{|c|c|c|c|c|c|c|c|}
\hline Category & Median & $\begin{array}{l}\text { Std. } \\
\text { Dev. }\end{array}$ & $\begin{array}{l}\text { Jarque } \\
\text { Bera }\end{array}$ & Category & Median & $\begin{array}{l}\text { Std. } \\
\text { Dev. }\end{array}$ & $\begin{array}{c}\text { Jarque } \\
\text { Bera }\end{array}$ \\
\hline Eurozone Small-Cap & & & & Europe Large-Cap Value & & & \\
\hline Male & $0.69 \%$ & $5.61 \%$ & 0.00 & Male & $0.03 \%$ & $4.95 \%$ & 0.03 \\
\hline Female & $0.62 \%$ & $5.58 \%$ & 0.00 & Female & $0.06 \%$ & $4.78 \%$ & 0.03 \\
\hline Male vs. Female & $-0.45 \%$ & $1.42 \%$ & 0.59 & Male vs. Female & $-0.10 \%$ & $0.64 \%$ & 0.00 \\
\hline $\mathrm{R}_{\mathrm{m}}$ & $0.73 \%$ & $8.47 \%$ & 0.05 & $\mathrm{R}_{\mathrm{m}}$ & $-0.71 \%$ & $5.75 \%$ & 0.10 \\
\hline SMB & $0.25 \%$ & $2.42 \%$ & 0.71 & SMB & $0.50 \%$ & $2.72 \%$ & 0.06 \\
\hline $\mathrm{HML}$ & $-0.35 \%$ & $2.66 \%$ & 0.00 & HML & $-0.35 \%$ & $2.16 \%$ & 0.00 \\
\hline $\mathrm{R}_{\mathrm{B}}$ & $0.06 \%$ & $1.05 \%$ & 0.35 & $\mathrm{R}_{\mathrm{B}}$ & $0.06 \%$ & $1.05 \%$ & 0.35 \\
\hline France Large-Cap & & & & $\begin{array}{l}\text { Europe Large-Cap } \\
\text { Growth }\end{array}$ & & & \\
\hline Male & $0.02 \%$ & $5.12 \%$ & 0.27 & Male & $0.09 \%$ & $5.01 \%$ & 0.00 \\
\hline Female & $0.24 \%$ & $5.50 \%$ & 0.44 & Female & $0.03 \%$ & $4.98 \%$ & 0.00 \\
\hline Male vs. Female & $0.08 \%$ & $0.61 \%$ & 0.76 & Male vs. Female & $-0.23 \%$ & $1.63 \%$ & 0.77 \\
\hline $\mathrm{R}_{\mathrm{m}}$ & $-0.37 \%$ & $5.55 \%$ & 0.49 & $\mathrm{R}_{\mathrm{m}}$ & $0.68 \%$ & $4.38 \%$ & 0.03 \\
\hline
\end{tabular}




\begin{tabular}{|c|c|c|c|c|c|c|c|}
\hline $\mathrm{SMB}$ & $0.25 \%$ & $2.42 \%$ & 0.71 & SMB & $0.50 \%$ & $2.72 \%$ & 0.06 \\
\hline $\mathrm{HML}$ & $-0.35 \%$ & $2.66 \%$ & 0.00 & $\mathrm{HML}$ & $-0.35 \%$ & $2.16 \%$ & 0.00 \\
\hline $\mathrm{R}_{\mathrm{B}}$ & $0.06 \%$ & $1.05 \%$ & 0.35 & $\mathrm{R}_{\mathrm{B}}$ & $0.06 \%$ & $1.05 \%$ & 0.35 \\
\hline \multicolumn{4}{|l|}{ Eurozone Large-Cap } & \multicolumn{4}{|l|}{ Europe Large-Cap Blend } \\
\hline Male & $0.24 \%$ & $5.27 \%$ & 0.05 & Male & $0.19 \%$ & $4.81 \%$ & 0.02 \\
\hline Female & $0.09 \%$ & $5.14 \%$ & 0.05 & Female & $0.57 \%$ & $4.77 \%$ & 0.00 \\
\hline Male vs. Female & $-0.03 \%$ & $0.47 \%$ & 0.00 & Male vs. Female & $-0.15 \%$ & $0.66 \%$ & 0.51 \\
\hline $\mathrm{R}_{\mathrm{m}}$ & $-0.29 \%$ & $5.65 \%$ & 0.18 & $\mathrm{R}_{\mathrm{m}}$ & $-0.10 \%$ & $4.91 \%$ & 0.19 \\
\hline SMB & $0.25 \%$ & $2.42 \%$ & 0.71 & SMB & $0.50 \%$ & $2.72 \%$ & 0.06 \\
\hline $\mathrm{HML}$ & $-0.35 \%$ & $2.66 \%$ & 0.00 & $\mathrm{HML}$ & $-0.35 \%$ & $2.16 \%$ & 0.00 \\
\hline $\mathrm{R}_{\mathrm{B}}$ & $0.06 \%$ & $1.05 \%$ & 0.35 & $\mathrm{R}_{\mathrm{B}}$ & $0.06 \%$ & $1.05 \%$ & 0.35 \\
\hline \multicolumn{4}{|l|}{ Europe Small-Cap } & \multicolumn{4}{|l|}{ Eurozone Mid-Cap } \\
\hline Male & $0.18 \%$ & $5.26 \%$ & 0.00 & Male & $0.17 \%$ & $5.46 \%$ & 0.05 \\
\hline $\mathrm{R}_{\mathrm{m}}$ & $0.22 \%$ & $6.31 \%$ & 0.00 & $\mathrm{R}_{\mathrm{m}}$ & $0.24 \%$ & $6.13 \%$ & 0.04 \\
\hline $\mathrm{SMB}$ & $0.50 \%$ & $2.72 \%$ & 0.06 & SMB & $0.25 \%$ & $2.42 \%$ & 0.71 \\
\hline $\mathrm{HML}$ & $-0.35 \%$ & $2.16 \%$ & 0.00 & $\mathrm{HML}$ & $-0.35 \%$ & $2.66 \%$ & 0.00 \\
\hline $\mathrm{R}_{\mathrm{B}}$ & $0.06 \%$ & $1.05 \%$ & 0.35 & $\mathrm{R}_{\mathrm{B}}$ & $0.06 \%$ & $1.05 \%$ & 0.35 \\
\hline
\end{tabular}

Note: This table reports summary statistics for the two equally-weighted portfolios of male and female managers respectively. Table also reports returns statistics for a strategy that is long in male managers and short in female managers (Male vs. Female) along with the statistics of the employed benchmark portfolios. $\mathrm{R}_{\mathrm{m}}$ is the market portfolio return defined for each investment category, SMB is the small vs. large strategy portfolio returns whereas HML is the value vs. growth strategy portfolio returns properly constructed for each investment category. $\mathrm{R}_{\mathrm{B}}$ is the returns of the Barclays Corporate \& Government Total Return fixed income index. The Jarque-Bera test statistic reported in the last column measures the degree of normality for the returns distribution.

Table 3 cont.

Summary statistics for European equity funds and their benchmarks

\begin{tabular}{|c|c|c|c|c|c|c|c|}
\hline Category & Median & $\begin{array}{l}\text { Std. } \\
\text { Dev. }\end{array}$ & $\begin{array}{c}\text { Jarque } \\
\text { Bera }\end{array}$ & Category & Median & $\begin{array}{l}\text { Std. } \\
\text { Dev. }\end{array}$ & $\begin{array}{c}\text { Jarque } \\
\text { Bera }\end{array}$ \\
\hline \multicolumn{4}{|l|}{ Europe Mid-Cap } & \multicolumn{4}{|l|}{ France Small/Mid-Cap } \\
\hline Male & $0.15 \%$ & $5.60 \%$ & 0.01 & Male & $0.53 \%$ & $5.10 \%$ & 0.00 \\
\hline Female & $0.53 \%$ & $5.54 \%$ & 0.01 & Female & $0.66 \%$ & $5.31 \%$ & 0.01 \\
\hline Male vs. Female & $-0.37 \%$ & $1.27 \%$ & 0.76 & Male vs. Female & $-0.07 \%$ & $0.97 \%$ & 0.65 \\
\hline $\mathrm{R}_{\mathrm{m}}$ & $0.52 \%$ & $5.62 \%$ & 0.01 & $\mathrm{R}_{\mathrm{m}}$ & $0.64 \%$ & $6.04 \%$ & 0.03 \\
\hline SMB & $0.50 \%$ & $2.72 \%$ & 0.06 & SMB & $0.25 \%$ & $2.42 \%$ & 0.71 \\
\hline $\mathrm{HML}$ & $-0.35 \%$ & $2.16 \%$ & 0.00 & HML & $-0.35 \%$ & $2.66 \%$ & 0.00 \\
\hline $\mathrm{R}_{\mathrm{B}}$ & $0.06 \%$ & $1.05 \%$ & 0.35 & $\mathrm{R}_{\mathrm{B}}$ & $0.06 \%$ & $1.05 \%$ & 0.35 \\
\hline \multicolumn{4}{|c|}{ Germany Small/Mid-Cap } & \multicolumn{4}{|l|}{ Germany Large-Cap } \\
\hline Male & $1.25 \%$ & $6.76 \%$ & 0.00 & Male & $0.99 \%$ & $6.43 \%$ & 0.00 \\
\hline $\mathrm{R}_{\mathrm{m}}$ & $0.56 \%$ & $6.95 \%$ & 0.00 & $\mathrm{R}_{\mathrm{m}}$ & $1.12 \%$ & $6.12 \%$ & 0.01 \\
\hline SMB & $0.25 \%$ & $2.42 \%$ & 0.71 & SMB & $0.25 \%$ & $2.42 \%$ & 0.71 \\
\hline
\end{tabular}




\begin{tabular}{|c|c|c|c|c|c|c|c|}
\hline HML & $-0.35 \%$ & $2.66 \%$ & 0.00 & $\mathrm{HML}$ & $-0.35 \%$ & $2.66 \%$ & 0.00 \\
\hline $\mathrm{R}_{\mathrm{B}}$ & $0.06 \%$ & $1.05 \%$ & 0.35 & $\mathrm{R}_{\mathrm{B}}$ & $0.06 \%$ & $1.05 \%$ & 0.35 \\
\hline \multicolumn{4}{|l|}{ Italy Equity } & \multicolumn{4}{|l|}{ Spain Equity } \\
\hline Male & $-0.79 \%$ & $5.74 \%$ & 0.41 & Male & $0.18 \%$ & $5.58 \%$ & 0.31 \\
\hline Female & $-0.64 \%$ & $5.94 \%$ & 0.55 & Female & $-0.20 \%$ & $5.70 \%$ & 0.29 \\
\hline Male vs. Female & $0.04 \%$ & $0.51 \%$ & 0.72 & Male vs. Female & $0.16 \%$ & $1.21 \%$ & 0.48 \\
\hline $\mathrm{R}_{\mathrm{m}}$ & $-1.04 \%$ & $6.25 \%$ & 0.60 & $\mathrm{R}_{\mathrm{m}}$ & $0.03 \%$ & $6.36 \%$ & 0.31 \\
\hline SMB & $0.25 \%$ & $2.42 \%$ & 0.71 & SMB & $0.25 \%$ & $2.42 \%$ & 0.71 \\
\hline $\mathrm{HML}$ & $-0.35 \%$ & $2.66 \%$ & 0.00 & $\mathrm{HML}$ & $-0.35 \%$ & $2.66 \%$ & 0.00 \\
\hline $\mathrm{R}_{\mathrm{B}}$ & $0.06 \%$ & $1.05 \%$ & 0.35 & $\mathrm{R}_{\mathrm{B}}$ & $0.06 \%$ & $1.05 \%$ & 0.35 \\
\hline
\end{tabular}

Note: This table reports summary statistics for the two equally-weighted portfolios of male and female managers respectively. Table also reports returns statistics for a strategy that is long in male managers and short in female managers (Male vs. Female) along with the statistics of the employed benchmark portfolios. $R_{m}$ is the market portfolio return defined for each category, SMB is the small vs. large strategy portfolio returns whereas HML is the value vs. growth strategy portfolio returns properly constructed for each investment category. $\mathrm{R}_{\mathrm{B}}$ is the returns of the Barclays Corporate \& Government Total Return fixed income index. The Jarque-Bera test statistic reported in the last column measures the degree of normality for the returns distribution.

Table 4

Designated benchmarks per investment style

\begin{tabular}{|ll|}
\hline Investment Category & Benchmark Index \\
\hline Eurozone Small-Cap Equity & MSCI EMU Small Cap \\
\hline Eurozone Mid-Cap Equity & MSCI EMU Mid \\
\hline Eurozone Large-Cap Equity & MSCI EMU \\
\hline Europe Small-Cap Equity & MSCI Europe Small Cap \\
\hline Europe Mid-Cap Equity & Stoxx Europe Mid 200 \\
\hline Europe Large-Cap Value Equity & MSCI Europe Value \\
\hline Europe Large-Cap Growth Equity & MSCI Europe Growth \\
\hline Europe Large-Cap Blend Equity & MSCI Europe \\
\hline France Large-Cap Equity & Euronext Paris CAC 40 \\
\hline France Small/Mid-Cap Equity & Euronext Paris CAC Mid 100 \\
\hline Germany Large-Cap Equity & DAX \\
\hline Germany Small/Mid-Cap Equity & MSCI Germany Small Cap \\
\hline Italy Equity & MSCI Italy \\
\hline Spain Equity & MSCI Spain \\
\hline
\end{tabular}

Note: This table reports the most suitable market benchmarks across investment categories defined by Morningstar. 
Table 5

Single factor model regression estimates

\begin{tabular}{|c|c|c|}
\hline \multicolumn{3}{|l|}{ Panel A: Number of significant 1 factor alphas } \\
\hline No. of significantly positive & 120 & \\
\hline No. of significantly negative & 9 & \\
\hline \multicolumn{3}{|l|}{ Panel B: Analysis by gender } \\
\hline No. of significantly positive 1 factor alphas & & $\begin{array}{l}\text { No. of funds in the } \\
\text { category }\end{array}$ \\
\hline Male & 98 & $299(33 \%)$ \\
\hline Female & 22 & $59(37 \%)$ \\
\hline \multicolumn{3}{|l|}{ No. of significantly negative 1 factor alphas } \\
\hline Male & 6 & $299(2 \%)$ \\
\hline Female & 3 & $59(5 \%)$ \\
\hline \multicolumn{3}{|l|}{ Panel C: Analysis by investment objective } \\
\hline No. of significantly positive 1 factor alphas & 120 & \\
\hline Eurozone Mid-Cap & 4 & 9 \\
\hline Eurozone Large-Cap & 37 & 96 \\
\hline Europe Large-Cap Value & 15 & 37 \\
\hline Europe Large-Cap Blend & 21 & 62 \\
\hline France Large-Cap & 28 & 54 \\
\hline France Small/Mid-Cap & 3 & 41 \\
\hline Italy Equity & 3 & 5 \\
\hline Spain Equity & 9 & 17 \\
\hline No. of significantly negative 1 factor alphas & 9 & \\
\hline Eurozone Small-Cap & 1 & 9 \\
\hline Eurozone Large-Cap & 1 & 96 \\
\hline Europe Small-Cap & 1 & 2 \\
\hline Europe Large-Cap Growth & 2 & 6 \\
\hline France Small/Mid-Cap & 4 & 41 \\
\hline
\end{tabular}

Note: This table reports overall OLS estimation results from the single factor securities selection model in Eq. (1) employing the Newey-West (1987) method for robust standard errors. Panel A of the table reports the number of significant positive and negative single factor alphas whereas Panel B presents the results grouped by manager gender. Panel $\mathrm{C}$ reports the significant alphas broken down by investment category. 
Table 6

Timing model I regression estimates

\begin{tabular}{|c|c|c|}
\hline \multicolumn{3}{|l|}{ Panel A: Number of significant timing coefficients } \\
\hline No. of significantly positive & 13 & \\
\hline No. of significantly negative & 123 & \\
\hline \multicolumn{3}{|l|}{ Panel B: Analysis by gender } \\
\hline No. of significantly positive timing coefficients & & $\begin{array}{l}\text { No. of funds in } \\
\text { the category }\end{array}$ \\
\hline Male & 12 & $299(4 \%)$ \\
\hline Female & 1 & $59(2 \%)$ \\
\hline \multicolumn{3}{|l|}{ No. of significantly negative timing coefficients } \\
\hline Male & 94 & $299(31 \%)$ \\
\hline Female & 29 & $59(49 \%)$ \\
\hline \multicolumn{3}{|l|}{ Panel C: Analysis by investment objective } \\
\hline \multicolumn{3}{|l|}{ No. of significantly positive timing coefficients } \\
\hline Eurozone Mid-Cap & 3 & 9 \\
\hline Eurozone Large-Cap & 5 & 96 \\
\hline Europe Mid-Cap & 1 & 12 \\
\hline Europe Large-Cap Value & 1 & 37 \\
\hline Europe Large-Cap Blend & 1 & 62 \\
\hline France Small/Mid-Cap & 1 & 41 \\
\hline Germany Large-Cap & 1 & 7 \\
\hline \multicolumn{3}{|l|}{ No. of significantly negative timing coefficients } \\
\hline Eurozone Small-Cap & 2 & 9 \\
\hline Eurozone Mid-Cap & 3 & 9 \\
\hline Eurozone Large-Cap & 22 & 96 \\
\hline Europe Small-Cap & 2 & 2 \\
\hline Europe Mid-Cap & 4 & 12 \\
\hline Europe Large-Cap Value & 30 & 37 \\
\hline Europe Large-Cap Growth & 1 & 6 \\
\hline Europe Large-Cap Blend & 26 & 62 \\
\hline France Large-Cap & 9 & 54 \\
\hline France Small/Mid-Cap & 17 & 41 \\
\hline Germany Large-Cap & 1 & 7 \\
\hline Germany Small/Mid-Cap & 1 & 1 \\
\hline Italy Equity & 3 & 5 \\
\hline Spain Equity & 2 & 17 \\
\hline
\end{tabular}


Note: This table reports overall OLS estimation results from the estimation of the Treynor \& Mazuy (1966) market timing model in Eq. (2) employing the Newey-West (1987) method for robust standard errors. Panel $A$ of the table reports the number of significant positive and negative timing coefficients whereas Panel B presents the results grouped by manager gender. Panel $C$ reports the significant timing coefficients broken down by investment category.

Table 7

Four factor model regression estimates

\begin{tabular}{|c|c|c|}
\hline \multicolumn{3}{|l|}{ Panel A: Number of significant $4 \mathrm{~F}$ alphas } \\
\hline No. of significantly positive & 116 & \\
\hline No. of significantly negative & 12 & \\
\hline \multicolumn{3}{|l|}{ Panel B: Analysis by gender } \\
\hline No. of significantly positive $4 F$ alphas & & $\begin{array}{c}\text { No. of } \\
\text { funds in } \\
\text { the } \\
\text { category }\end{array}$ \\
\hline Male & 96 & $299(32 \%)$ \\
\hline Female & 20 & $59(34 \%)$ \\
\hline \multicolumn{3}{|l|}{ No. of significantly negative $4 \mathrm{~F}$ alphas } \\
\hline Male & 9 & $299(3 \%)$ \\
\hline Female & 3 & $59(5 \%)$ \\
\hline \multicolumn{3}{|l|}{ Panel C: Analysis by investment objective } \\
\hline \multicolumn{3}{|l|}{ No. of significantly positive $4 \mathrm{~F}$ alphas } \\
\hline Eurozone Mid-Cap & 4 & 9 \\
\hline Eurozone Large-Cap & 47 & 96 \\
\hline Europe Large-Cap Value & 10 & 37 \\
\hline Europe Large-Cap Blend & 17 & 62 \\
\hline France Large-Cap & 24 & 54 \\
\hline France Small/Mid-Cap & 4 & 41 \\
\hline Italy Equity & 3 & 5 \\
\hline Spain Equity & 7 & 17 \\
\hline \multicolumn{3}{|l|}{ No. of significantly negative $4 F$ alphas } \\
\hline Eurozone Small-Cap & 1 & 9 \\
\hline Eurozone Large-Cap & 2 & 96 \\
\hline Europe Small-Cap & 1 & 2 \\
\hline Europe Large-Cap Growth & 2 & 6 \\
\hline France Large-Cap & 1 & 54 \\
\hline France Small/Mid-Cap & 4 & 41 \\
\hline Germany Large-Cap & 1 & 7 \\
\hline
\end{tabular}


Note: This table reports overall OLS estimation results from the four factor securities selection model in Eq. (2) employing the Newey-West (1987) method for robust standard errors. Panel A of the table reports the number of significant positive and negative four factor alphas whereas Panel $B$ presents the results grouped by manager gender. Panel $\mathrm{C}$ reports the significant multi factor alphas broken down by investment category.

Table 8

Fund exposures to risk factors

\begin{tabular}{|c|c|c|c|c|}
\hline Panel A: Sensitivity to risk factors & SMB & & HML & \\
\hline Number of significantly positive coefficients & 143 & $\begin{array}{l}\% \text { of funds in } \\
\text { the category }\end{array}$ & 28 & $\begin{array}{l}\% \text { of funds in } \\
\text { the category }\end{array}$ \\
\hline Male & 125 & $42 \%$ & 23 & $8 \%$ \\
\hline Female & 18 & $31 \%$ & 5 & $8 \%$ \\
\hline Number of significantly negative coefficients & 45 & & 102 & \\
\hline Male & 35 & $12 \%$ & 81 & $27 \%$ \\
\hline Female & 10 & $17 \%$ & 21 & $36 \%$ \\
\hline Panel B:Timing of risk factors & $\mathrm{SMB}^{2}$ & & $\mathrm{HML}^{2}$ & \\
\hline Number of significantly positive coefficients & 43 & $\begin{array}{l}\% \text { of funds in } \\
\text { the category }\end{array}$ & 41 & $\begin{array}{l}\% \text { of funds in } \\
\text { the category }\end{array}$ \\
\hline Male & 39 & $13 \%$ & 37 & $12 \%$ \\
\hline Female & 4 & $7 \%$ & 4 & $7 \%$ \\
\hline Number of significantly negative coefficients & 27 & & 38 & \\
\hline Male & 20 & $7 \%$ & 26 & $9 \%$ \\
\hline Female & 7 & $12 \%$ & 12 & $20 \%$ \\
\hline
\end{tabular}

Note: Panel A of the table reports the estimated fund loadings to the SMB \& HML factors derived from the four factor securities selection model in Eq. (2). Model has been estimated under the OLS method and the Newey-West (1987) method for robust standard errors. Panel B of the table reports the number of significant positive and negative factor timing coefficients derived from the factor timing model in Eq. (4). Model has been estimated using the OLS method and the Newey-West (1987) method for robust standard errors. 
Table 9

Securities selection model I

\begin{tabular}{|c|c|c|c|c|c|c|c|}
\hline Category & Intercept & $\beta_{p, 1}$ & Adj. $R^{2}$ & Category & Intercept & $\beta_{p, 1}$ & Adj. $R^{2}$ \\
\hline Eurozone Small-Cap & & & & $\begin{array}{l}\text { Europe Large-Cap } \\
\text { Blend } \\
\end{array}$ & & & \\
\hline Male & $-0.33 \%$ & $0.60 * * *$ & 0.80 & Male & $0.15 \% * *$ & $0.97 * * *$ & 0.98 \\
\hline Female & $-0.10 \%$ & $0.58^{* * *}$ & 0.77 & Female & $0.24 \% * *$ & $0.94^{* * *}$ & 0.94 \\
\hline Eurozone Mid-Cap & & & & France Large-Cap & & & \\
\hline Male & $0.25 \% *$ & $0.87^{* * *}$ & 0.96 & Male & $0.20 \% * *$ & $0.91 * * *$ & 0.98 \\
\hline Female & - & - & - & Female & $0.22 \% * *$ & $0.98^{* * *}$ & 0.97 \\
\hline Eurozone Large-Cap & & & & France Small/Mid-Cap & & & \\
\hline Male & $0.15 \% * *$ & $0.93^{* * *}$ & 0.99 & Male & $-0.10 \%$ & $0.82 * * *$ & 0.94 \\
\hline Female & $0.17 \% * *$ & $0.90 * * *$ & 0.98 & Female & $-0.03 \%$ & $0.86 * * *$ & 0.97 \\
\hline Europe Small-Cap & & & & Germany Large-Cap & & & \\
\hline Male & $-0.40 \%$ & $0.76 * * *$ & 0.84 & Male & $-0.04 \%$ & $1.02 * * *$ & 0.94 \\
\hline Female & - & - & - & Female & - & - & - \\
\hline Europe Mid-Cap & & & & $\begin{array}{l}\text { Germany Small/Mid- } \\
\text { Cap }\end{array}$ & & & \\
\hline Male & $0.05 \%$ & $0.97^{* * *}$ & 0.94 & Male & $0.13 \%$ & $0.91 * * *$ & 0.88 \\
\hline Female & $0.20 \%$ & $0.97 * * *$ & 0.96 & Female & - & - & - \\
\hline
\end{tabular}




\begin{tabular}{|c|c|c|c|c|c|c|c|}
\hline Category & Intercept & $\beta_{p, 1}$ & Adj. $R^{2}$ & Category & Intercept & $\beta_{p, 1}$ & Adj. $R^{2}$ \\
\hline Europe Large-Cap Value & & & & Italy Equity & & & \\
\hline Male & $0.22 \% * *$ & $0.84 * * *$ & 0.96 & Male & $0.31 \% * *$ & $0.90 * * *$ & 0.96 \\
\hline Female & $0.24 \% *$ & $0.80 * * *$ & 0.93 & Female & $0.28 \% *$ & $0.93 * * *$ & 0.96 \\
\hline Europe Large-Cap Growth & & & & Spain Equity & & & \\
\hline Male & $-0.27 \%$ & $1.05^{* * *}$ & 0.83 & Male & $0.26 \% *$ & $0.86^{* * *}$ & 0.95 \\
\hline Female & $-0.26 \%$ & $1.08 * * *$ & 0.91 & Female & $0.05 \%$ & $0.83 * * *$ & 0.86 \\
\hline
\end{tabular}

Note: This table reports the OLS estimation results from the single factor securities selection model in Eq. (1) employing the Newey-West (1987) method for robust standard errors for the two equally-weighted portfolios of male and female managed equity funds. $*, * *$ and $* * *$ respectively denote statistical significance at the $10 \%$, $5 \%$ and $1 \%$ levels. 
Table 10

Securities selection model II

\begin{tabular}{|c|c|c|c|c|c|c|c|c|c|c|c|c|c|}
\hline Category & Intercept & $\beta_{p, 1}$ & $\beta_{p, 2}$ & $\beta_{p, 3}$ & $\beta_{p, 4}$ & Adj. $R^{2}$ & Category & Intercept & $\beta_{\mathrm{p}, 1}$ & $\beta_{p, 2}$ & $\beta_{\mathrm{p}, 3}$ & $\beta_{p, 4}$ & Adj. $R^{2}$ \\
\hline Eurozone Small-Cap & & & & & & & \multicolumn{7}{|c|}{$\begin{array}{l}\text { Europe Large-Cap } \\
\text { Blend }\end{array}$} \\
\hline Male & $-0.37 \%$ & $0.57^{* * *}$ & 0.19 & 0.02 & -0.28 & 0.80 & Male & $0.11 \% *$ & $0.95^{* * *}$ & $0.10^{* * *}$ & -0.02 & -0.06 & 0.98 \\
\hline Female & $-0.13 \%$ & $0.59 * * *$ & 0.10 & -0.13 & -0.37 & 0.77 & Female & $0.17 \% *$ & $0.93^{* * *}$ & $0.14^{* * *}$ & -0.08 & -0.11 & 0.95 \\
\hline Eurozone Mid-Cap & & & & & & & \multicolumn{7}{|c|}{ France Large-Cap } \\
\hline Male & $0.21 \% *$ & $0.87^{* * *}$ & $0.11^{* *}$ & $-0.09 * *$ & -0.17 & 0.96 & Male & $0.14 \% * *$ & $0.92^{* * *}$ & 0.15 & $-0.07 * *$ & 0.07 & 0.98 \\
\hline Female & - & - & - & - & - & - & Female & $0.17 \% * *$ & $0.99 * * *$ & $0.10^{*}$ & -0.06 & 0.11 & 0.98 \\
\hline Eurozone Large-Cap & & & & & & & \multicolumn{7}{|c|}{ France Small/Mid-Cap } \\
\hline Male & $0.13 \% * *$ & $0.93^{* * *}$ & $0.05^{*}$ & $-0.04 *$ & 0.03 & 0.99 & Male & $-0.05 \%$ & $0.83^{* * *}$ & -0.13 & 0.04 & -0.11 & 0.95 \\
\hline Female & $0.19 \% * * *$ & $0.92^{* * *}$ & -0.05 & $-0.08^{* * *}$ & -0.08 & 0.98 & Female & $0.01 \%$ & $0.88^{* * *}$ & -0.10 & -0.02 & -0.15 & 0.97 \\
\hline Europe Small-Cap & & & & & & & \multicolumn{7}{|c|}{ Germany Large-Cap } \\
\hline Male & $-0.31 \%$ & $0.90^{* * *}$ & $-0.38^{* * *}$ & -0.12 & 0.11 & 0.85 & Male & $-0.18 \%$ & $1.04^{* * *}$ & $0.33^{* * *}$ & -0.03 & $0.46^{*}$ & 0.96 \\
\hline Female & - & - & - & - & - & - & Female & - & - & - & - & - & - \\
\hline Europe Mid-Cap & & & & & & & \multicolumn{7}{|c|}{$\begin{array}{l}\text { Germany Small/Mid- } \\
\text { Cap }\end{array}$} \\
\hline Male & $0.05 \%$ & $0.91 * * *$ & $0.15^{*}$ & 0.10 & $-0.28 *$ & 0.95 & Male & $0.22 \%$ & $0.94 * * *$ & $-0.27 *$ & 0.09 & 0.18 & 0.88 \\
\hline Female & $0.19 \%$ & $0.94 * * *$ & 0.08 & -0.01 & $-0.40 * * *$ & 0.96 & Female & - & - & - & - & - & - \\
\hline
\end{tabular}




\begin{tabular}{|c|c|c|c|c|c|c|c|c|c|c|c|c|c|}
\hline Category & Intercept & $\beta_{\mathrm{p}, 1}$ & $\boldsymbol{\beta}_{\mathrm{p}, 2}$ & $\boldsymbol{\beta}_{\mathrm{p}, 3}$ & $\beta_{p, 4}$ & Adj. $\mathrm{R}^{2}$ & Category & Intercept & $\beta_{p, 1}$ & $\boldsymbol{\beta}_{\mathrm{p}, 2}$ & $\boldsymbol{\beta}_{\mathrm{p}, 3}$ & $\beta_{p, 4}$ & Adj. $\mathrm{R}^{2}$ \\
\hline Europe Large-Cap Value & & & & & & & \begin{tabular}{|l|} 
Italy \\
Equity \\
\end{tabular} & & & & & & \\
\hline Male & $0.12 \%$ & $0.92^{* * *}$ & 0.04 & $-0.34 * * *$ & -0.07 & 0.97 & Male & $0.27 \% * *$ & $0.92 * * *$ & $0.16^{* * *}$ & $-0.08^{* *}$ & $-0.25 * *$ & 0.97 \\
\hline Female & $0.10 \%$ & $0.89 * * *$ & 0.09 & $-0.42 * * *$ & $-0.19 *$ & 0.96 & Female & $0.22 \% *$ & $0.95 * * *$ & $0.22 * * *$ & $-0.09 * *$ & $-0.25 * *$ & 0.97 \\
\hline $\begin{array}{l}\text { Europe Large-Cap } \\
\text { Growth }\end{array}$ & & & & & & & Spain Equit & & & & & & \\
\hline Male & $-0.31 \%$ & $0.92^{* * *}$ & $0.38 * * *$ & $0.22 * * *$ & 0.12 & 0.87 & Male & $0.18 \%$ & $0.85 * * *$ & $0.27^{* * *}$ & 0.01 & -0.24 & 0.96 \\
\hline Female & $-0.29 \% * *$ & $0.96 * * *$ & $0.37 * * *$ & $0.21 * * *$ & -0.11 & 0.95 & Female & $-0.10 \%$ & $0.86 * * *$ & $0.50 * * *$ & $-0.14 *$ & $-0.44^{* *}$ & 0.91 \\
\hline
\end{tabular}

Note: This table reports the OLS estimation results from the four factor securities selection model in Eq. (2) employing the Newey-West (1987) method for robust standard errors for the two equally-weighted portfolios of male and female managed equity funds. ${ }^{*}, * *$ and $* * *$ respectively denote statistical significance at the $10 \%, 5 \%$ and $1 \%$ levels. 
Table 11

Timing model I

\begin{tabular}{|c|c|c|c|c|c|c|c|c|c|}
\hline Category & Intercept & $\beta_{p}$ & $c_{p}$ & Adj. $R^{2}$ & Category & Intercept & $\beta_{p}$ & $C_{p}$ & Adj. $\mathrm{R}^{2}$ \\
\hline Eurozone Small-Cap & & & & & $\begin{array}{l}\text { Europe Large-Cap } \\
\text { Blend }\end{array}$ & & & & \\
\hline Female & $0.20 \%$ & $0.56 * * *$ & $-0.43 * * *$ & 0.78 & Female & $0.47 \% * * *$ & $0.91 * * *$ & $-1.02 * * *$ & 0.95 \\
\hline Eurozone Mid-Cap & & & & & France Large-Cap & & & & \\
\hline Female & - & - & - & - & Female & $0.23 \% * * *$ & $0.98^{* * *}$ & -0.04 & 0.97 \\
\hline Eurozone Large-Cap & & & & & France Small/Mid-Cap & & & & \\
\hline Male & $0.22 \% * *$ & $0.92 * * *$ & $-0.25 * *$ & 0.99 & Male & $0.09 \%$ & $0.80 * * *$ & $-0.54 * *$ & 0.95 \\
\hline Female & $0.29 \% * * *$ & $0.89 * * *$ & $-0.40^{* * *}$ & 0.98 & Female & $0.08 \%$ & $0.85^{* * *}$ & -0.29 & 0.97 \\
\hline Female & - & - & - & - & Female & - & - & - & - \\
\hline Europe Mid-Cap & & & & & $\begin{array}{l}\text { Germany Small/Mid- } \\
\text { Cap }\end{array}$ & & & & \\
\hline Male & $0.07 \%$ & $0.97 * * *$ & -0.06 & 0.94 & Male & $0.43 \% *$ & $0.89 * * *$ & $-0.62 * * *$ & 0.88 \\
\hline Female & $0.32 \% * *$ & $0.95 * * *$ & $-0.39 * *$ & 0.96 & Female & - & - & - & - \\
\hline
\end{tabular}


Table 11 (Continued)

Timing model I

\begin{tabular}{|c|c|c|c|c|c|c|c|c|c|}
\hline Category & Intercept & $\beta_{p}$ & $c_{p}$ & $\begin{array}{c}\text { Adj } \\
\text { R2 } \\
\end{array}$ & Category & Intercept & $\beta_{p}$ & $c_{p}$ & $\begin{array}{l}\text { Adj } \\
\text { R2 } \\
\end{array}$ \\
\hline Europe Large-Cap Value & & & & & Italy Equity & & & & \\
\hline Male & $0.49 \% * * *$ & $0.83^{* * *}$ & $-0.85 * * *$ & 0.97 & Male & $0.45 \% * * *$ & $0.89 * * *$ & -0.36 & 0.96 \\
\hline Female & $0.57 \% * * *$ & $0.79 * * *$ & $-1.05^{* * *}$ & 0.95 & Female & $0.43 \% * * *$ & $0.93^{* * *}$ & $-0.41^{*}$ & 0.96 \\
\hline Europe Large-Cap Growth & & & & & Spain Equit & & & & \\
\hline Male & $-0.12 \%$ & $1.02 * * *$ & -0.81 & 0.83 & Male & $0.31 \% *$ & $0.85^{* * *}$ & -0.13 & 0.95 \\
\hline Female & $-0.14 \%$ & $1.06 * * *$ & -0.64 & 0.91 & Female & $0.15 \%$ & $0.83^{* * *}$ & -0.26 & 0.86 \\
\hline
\end{tabular}

Note: This table reports the OLS estimation results from the Treynor \& Mazuy (1966) market timing model in Eq. (3) employing the Newey-West (1987) method for robust standard errors for the two equally-weighted portfolios of male and female managed funds. ${ }^{*}, * *$ and ${ }^{* * *}$ respectively denote statistical significance at the $10 \%, 5 \%$ and $1 \%$ levels.

Table 12

Timing model II 


\begin{tabular}{|c|c|c|c|c|c|c|c|c|c|c|c|c|c|c|c|c|c|}
\hline Category & Intercept & $\beta_{p, 1}$ & $\beta_{p, 2}$ & $\beta_{p, 3}$ & $c_{p, 1}$ & $c_{p, 2}$ & $\mathrm{c}_{\mathrm{p}, 3}$ & Adj. $\mathrm{R}^{2}$ & Category & Intercept & $\underline{\beta_{p, 1}}$ & $\beta_{p, 2}$ & $\beta_{p, 3}$ & $\underline{c_{p, 1}}$ & $c_{p, 2}$ & $\mathrm{c}_{\mathrm{p}, 3}$ & $\begin{array}{c}\text { Adj. } \\
\mathrm{R}^{2} \\
\end{array}$ \\
\hline $\begin{array}{l}\text { Eurozone } \\
\text { Small-Cap }\end{array}$ & & & & & & & & & $\begin{array}{l}\text { Europe Large-Cap } \\
\text { Blend }\end{array}$ & & & & & & & & \\
\hline Male & $-0.59 \%$ & $0.56^{* * *}$ & 0.04 & -0.10 & $-0.66 * * *$ & $7.38^{*}$ & $3.71^{* * *}$ & 0.82 & Male & $0.26 \% * * *$ & $0.93^{* * *}$ & $0.12^{* * *}$ & 0.01 & $-0.48^{*}$ & 0.21 & -1.39 & 0.98 \\
\hline Female & $-0.17 \%$ & $0.58^{* * *}$ & -0.03 & $-0.22 * *$ & $-0.72 * * *$ & 6.53 & $2.38^{*}$ & 0.78 & Female & $0.48 \% * * *$ & $0.90^{* * *}$ & $0.18^{* * *}$ & -0.04 & -0.72 & -0.12 & -3.21 & 0.95 \\
\hline \multicolumn{9}{|l|}{$\begin{array}{l}\text { Eurozone } \\
\text { Mid-Cap }\end{array}$} & \multicolumn{9}{|l|}{ France Large-Cap } \\
\hline Male & $0.25 \%$ & $0.88^{* * *}$ & 0.11 & $-0.10 * *$ & 0.04 & -0.78 & -0.22 & 0.96 & Male & $0.19 \% * *$ & $0.90^{* * *}$ & $0.14^{* * *}$ & -0.05 & $-0.49^{* * *}$ & 0.69 & 0.85 & 0.98 \\
\hline Female & - & - & - & - & - & - & - & - & Female & $0.10 \%$ & $0.98^{* * *}$ & 0.08 & -0.06 & -0.25 & 1.73 & 0.76 & 0.98 \\
\hline \multicolumn{9}{|l|}{$\begin{array}{l}\text { Eurozone } \\
\text { Large-Cap } \\
\end{array}$} & \multicolumn{9}{|l|}{ France Small/Mid-Cap } \\
\hline Male & $0.20 \% * *$ & $0.92^{* * *}$ & $0.06^{*}$ & -0.02 & $-0.27 * *$ & -0.13 & 0.18 & 0.99 & Male & $0.01 \%$ & $0.80^{* * *}$ & -0.13 & 0.04 & $-0.78^{* *}$ & 2.05 & $1.31^{* *}$ & 0.95 \\
\hline Female & $0.31 \% * * *$ & $0.91^{* * *}$ & -0.03 & -0.06 & -0.21 & -1.19 & 0.03 & 0.98 & Female & $0.05 \%$ & $0.87^{* * *}$ & -0.10 & -0.03 & -0.30 & -0.26 & 1.08 & 0.97 \\
\hline \multicolumn{9}{|l|}{$\begin{array}{l}\text { Europe } \\
\text { Small-Cap } \\
\end{array}$} & \multicolumn{9}{|l|}{ Germany Large-Cap } \\
\hline Male & $0.14 \%$ & $0.83^{* * *}$ & $-0.27^{* * *}$ & 0.01 & $-1.23^{* * *}$ & $4.93^{*}$ & $-6.49 * * *$ & 0.87 & Male & $0.08 \%$ & $0.99 * * *$ & $0.37^{* * *}$ & 0.05 & -0.55 & -1.40 & 0.83 & 0.96 \\
\hline Female & & & & & & & & & Female & - & - & - & - & - & - & - & - \\
\hline \multicolumn{9}{|c|}{ Europe Mid-Cap } & \multicolumn{9}{|l|}{ Germany Small/Mid-Cap } \\
\hline Male & $0.10 \%$ & $0.91^{* * *}$ & 0.15 & 0.07 & -0.66 & $4.58^{* *}$ & $-4.50 * *$ & 0.95 & Male & $0.41 \%$ & $0.87^{* * *}$ & -0.23 & 0.16 & $-0.87^{*}$ & 2.08 & 1.77 & 0.89 \\
\hline Female & $0.35 \% * *$ & $0.95^{* * *}$ & 0.10 & -0.04 & -0.46 & 2.36 & $-4.94 * *$ & 0.96 & Female & - & - & - & - & - & - & - & - \\
\hline
\end{tabular}

Table 12 Continued 
Timing model II

\begin{tabular}{|c|c|c|c|c|c|c|c|c|c|c|c|c|c|c|c|c|c|}
\hline Category & Intercept & $\beta_{p, 1}$ & $\boldsymbol{\beta}_{p, 2}$ & $\boldsymbol{\beta}_{\mathrm{p}, 3}$ & $c_{p, 1}$ & $c_{p, 2}$ & $c_{p, 3}$ & Adj. $\mathrm{R}^{2}$ & Category & Intercept & $\beta_{p, 1}$ & $\boldsymbol{\beta}_{p, 2}$ & $\beta_{p, 3}$ & $c_{p, 1}$ & $c_{p, 2}$ & $\mathrm{c}_{\mathrm{p}, 3}$ & Adj. $\mathrm{R}^{2}$ \\
\hline $\begin{array}{l}\text { Europe } \\
\text { Large-Cap } \\
\text { Value }\end{array}$ & & & & & & & & & Italy Equity & & & & & & & & \\
\hline Male & $0.35 \% * * *$ & $0.90^{* * *}$ & $0.07 *$ & $-0.29 * * *$ & $-0.60 * * *$ & 0.36 & -1.40 & 0.98 & Male & $0.41 \% * *$ & $0.90 * * *$ & $0.17^{* * *}$ & $-0.07^{*}$ & $-0.47^{* *}$ & -0.49 & 0.68 & 0.97 \\
\hline Female & $0.43 \% * * *$ & $0.88^{* * *}$ & $0.13^{* * *}$ & $-0.39 * * *$ & -0.37 & -1.31 & $-2.67 *$ & 0.97 & Female & $0.41 \% * * *$ & $0.93^{* * *}$ & $0.24^{* * *}$ & -0.07 & $-0.44^{* *}$ & -1.25 & 0.36 & 0.97 \\
\hline $\begin{array}{l}\text { Europe } \\
\text { Large-Cap } \\
\text { Growth } \\
\end{array}$ & & & & & & & & & Spain Equity & & & & & & & & \\
\hline Male & $-0.19 \%$ & $0.88^{* * *}$ & $0.35^{* * *}$ & $0.25^{* *}$ & -0.96 & -1.05 & 3.51 & 0.87 & Male & $0.31 \% *$ & $0.84^{* * *}$ & $0.28^{* * *}$ & 0.03 & -0.12 & -1.46 & -0.23 & 0.96 \\
\hline Female & $-0.15 \%$ & $0.94^{* * *}$ & $0.37^{* * *}$ & $0.21^{* * *}$ & -1.02 & 2.04 & -2.13 & 0.95 & Female & $0.11 \%$ & $0.84^{* * *}$ & $0.52^{* * *}$ & -0.12 & -0.26 & -2.92 & 0.42 & 0.91 \\
\hline
\end{tabular}

Note: This table reports the OLS estimation results from the augmented Treynor \& Mazuy (1966) factor timing model in Eq. (4) employing the Newey-West (1987) method

for robust standard errors for the two equally-weighted portfolios of male and female managed funds. ${ }^{*}, * *$ and $* * *$ respectively denote statistical significance at the $10 \%, 5 \%$ and $1 \%$ levels.

Table 13

Multi factor securities selection model: Quantile regression 


\begin{tabular}{|c|c|c|c|c|c|c|c|c|c|c|c|c|c|c|c|}
\hline & & & Intercept & $\beta_{p, 1}$ & $\beta_{p, 2}$ & $\boldsymbol{\beta}_{p, 3}$ & $\beta_{p, 4}$ & & & & Intercept & $\beta_{p, 1}$ & $\beta_{p, 2}$ & $\boldsymbol{\beta}_{\mathrm{p}, 3}$ & $\beta_{p, 4}$ \\
\hline \multirow{10}{*}{$\begin{array}{l}\text { Eurozone Small- } \\
\text { Cap }\end{array}$} & \multirow{5}{*}{ Male } & q05 & $-5.13 \% * * *$ & $0.66^{* * *}$ & -0.24 & 0.46 & $-1.43^{*}$ & & \multirow{5}{*}{ Male } & q05 & $-3.30 \% * * *$ & $0.93^{* * *}$ & $-0.54^{* * *}$ & -0.06 & 0.28 \\
\hline & & $\mathrm{q} 25$ & $-1.58 \% * *$ & $0.57^{* * *}$ & 0.20 & 0.20 & -0.35 & & & $\mathrm{q} 25$ & $-1.75 \% * * *$ & $0.98^{* * *}$ & $-0.52^{* * *}$ & -0.18 & 0.16 \\
\hline & & q50 & $-0.49 \%$ & $0.53^{* * *}$ & $0.29 *$ & 0.10 & -0.04 & & & q50 & $-0.27 \%$ & $0.83^{* * *}$ & -0.24 & 0.06 & -0.18 \\
\hline & & $\mathrm{q} 75$ & $1.19 \% * * *$ & $0.52^{* * *}$ & $0.33^{* * *}$ & -0.02 & -0.10 & & & $\mathrm{q} 75$ & $0.75 \% * *$ & $0.82^{* * *}$ & -0.26 & -0.10 & 0.21 \\
\hline & & q95 & $2.71 \% * * *$ & $0.52^{* * *}$ & 0.28 & 0.04 & 0.06 & Furnne Small-Can & & q95 & $3.35 \% * * *$ & $0.95^{* * *}$ & -0.67 & 0.23 & 0.61 \\
\hline & \multirow{5}{*}{ Female } & $\mathrm{q} 05$ & $-5.28 \% * * *$ & $0.68^{* * *}$ & -0.09 & -0.35 & -1.23 & & \multirow{5}{*}{ Female } & q05 & - & - & - & - & - \\
\hline & & $\mathrm{q} 25$ & $-1.52 \% * *$ & $0.61^{* * *}$ & -0.12 & -0.08 & -0.76 & & & $\mathrm{q} 25$ & - & - & - & - & - \\
\hline & & $\mathrm{q} 50$ & $0.26 \%$ & $0.58^{* * *}$ & 0.07 & -0.04 & -0.53 & & & q50 & - & - & - & - & - \\
\hline & & $\mathrm{q} 75$ & $1.45 \% * * *$ & $0.55^{* * *}$ & 0.16 & -0.09 & 0.15 & & & $\mathrm{q} 75$ & - & - & - & - & - \\
\hline & & q95 & $3.79 \% * * *$ & $0.46^{* * *}$ & $0.38^{*}$ & 0.36 & 0.11 & & & q95 & - & - & - & - & - \\
\hline \multirow{10}{*}{$\begin{array}{l}\text { Eurozone Mid- } \\
\text { Cap }\end{array}$} & \multirow{5}{*}{ Male } & q05 & $-1.56 \% * * *$ & $0.95^{* * *}$ & 0.16 & -0.18 & -0.25 & \multirow{10}{*}{ Europe Mid-Cap } & \multirow{5}{*}{ Male } & q05 & $-2.36 \% * * *$ & $1.02^{* * *}$ & 0.16 & 0.03 & 0.04 \\
\hline & & $\mathrm{q} 25$ & $-0.48 \% * * *$ & $0.89^{* * *}$ & 0.10 & $-0.10^{*}$ & -0.11 & & & $\mathrm{q} 25$ & $-0.68 \% * * *$ & $0.88^{* * *}$ & 0.14 & 0.01 & -0.05 \\
\hline & & $\mathrm{q} 50$ & $0.27 \%$ & $0.86^{* * *}$ & 0.10 & $-0.09 *$ & -0.16 & & & $\mathrm{q} 50$ & $0.08 \%$ & $0.87^{* * *}$ & 0.14 & 0.11 & -0.20 \\
\hline & & $\mathrm{q} 75$ & $0.85 \% * * *$ & $0.81^{* * *}$ & 0.16 & 0.02 & $-0.20 *$ & & & $\mathrm{q} 75$ & $0.93 \% * * *$ & $0.92^{* * *}$ & 0.15 & 0.09 & $-0.44 * * *$ \\
\hline & & q95 & $1.92 \% * * *$ & $0.76^{* * *}$ & $0.41^{* * *}$ & $-0.22^{* *}$ & -0.15 & & & q95 & $2.65 \% * * *$ & $0.89 * * *$ & -0.09 & $0.46^{* *}$ & $-0.55^{* *}$ \\
\hline & \multirow{5}{*}{ Female } & q05 & - & - & - & - & - & & \multirow{5}{*}{ Female } & q05 & $-1.52 \% * * *$ & $0.98^{* * *}$ & 0.07 & -0.04 & $-0.88^{* * *}$ \\
\hline & & $\mathrm{q} 25$ & - & - & - & - & - & & & $\mathrm{q} 25$ & $-0.48 \% * * *$ & $0.95^{* * *}$ & 0.04 & -0.08 & $-0.41 * * *$ \\
\hline & & q50 & - & - & - & - & - & & & q50 & $0.21 \% *$ & $0.90^{* * *}$ & 0.12 & 0.05 & $-0.37 * * *$ \\
\hline & & $q 75$ & - & - & - & - & - & & & $\mathrm{q} 75$ & $0.71 \% * * *$ & $0.92^{* * *}$ & 0.09 & 0.07 & -0.21 \\
\hline & & q95 & - & - & - & - & - & & & q95 & $2.10 \% * * *$ & $0.85^{* * *}$ & 0.09 & 0.33 & -0.70 \\
\hline Eurozone Large- & Male & q05 & $-0.91 \% * * *$ & $0.94^{* * *}$ & 0.06 & 0.02 & 0.04 & Europe Large-Cap & Male & q05 & $-1.50 \% * * *$ & $0.93^{* * *}$ & 0.06 & $-0.37^{* * *}$ & -0.17 \\
\hline
\end{tabular}




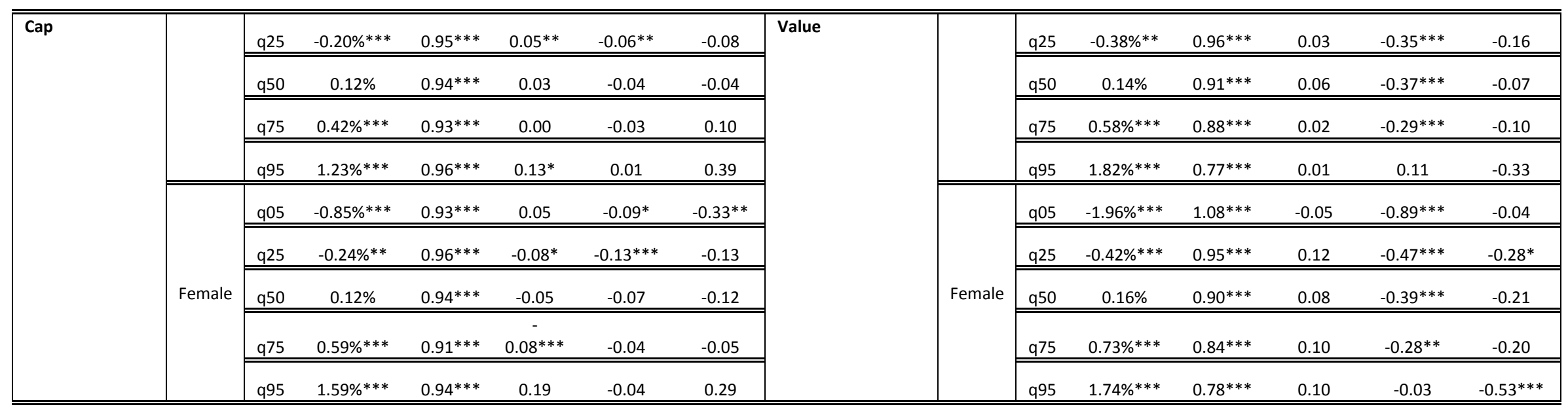




\begin{tabular}{|c|c|c|c|c|c|c|c|c|c|c|c|c|c|c|c|}
\hline \multirow{10}{*}{$\begin{array}{l}\text { Europe Large-Cap } \\
\text { Growth }\end{array}$} & \multirow{5}{*}{ Male } & $\mathrm{q} 05$ & $-2.92 \% * * *$ & $0.96 * * *$ & 0.43 & 0.12 & -0.59 & \multirow{10}{*}{$\begin{array}{l}\text { France } \\
\text { Small/Mid-Cap }\end{array}$} & \multirow{5}{*}{ Male } & $\mathrm{q} 05$ & $-1.88 \% * * *$ & $0.92 * * *$ & -0.09 & 0.01 & $-0.44 *$ \\
\hline & & $\mathrm{q} 25$ & $-1.33 \% * * *$ & $0.96 * * *$ & $0.35^{* * *}$ & 0.23 & 0.07 & & & $\mathrm{q} 25$ & $-0.73 \%^{* *}$ & $0.81^{* * *}$ & -0.14 & 0.00 & -0.17 \\
\hline & & q50 & $-0.16 \%$ & $0.85^{* * *}$ & $0.35^{* * *}$ & $0.37^{* * *}$ & -0.06 & & & q50 & $0.00 \%$ & $0.82^{* * *}$ & -0.11 & -0.03 & -0.05 \\
\hline & & $\mathrm{q} 75$ & $1.14 \% * * *$ & $0.97 * * *$ & $0.29 * * *$ & 0.18 & 0.44 & & & $\mathrm{q} 75$ & $0.71 \%^{* * *}$ & $0.81^{* * *}$ & -0.11 & 0.04 & 0.06 \\
\hline & & q95 & $2.66 \% * * *$ & $1.07^{* * *}$ & 0.17 & 0.08 & $0.78^{* * *}$ & & & q95 & $1.50 \% * * *$ & $0.73^{* * *}$ & -0.16 & 0.14 & -0.20 \\
\hline & \multirow{5}{*}{ Female } & q05 & $-2.62 \% * * *$ & $1.04^{* * *}$ & $0.56^{* * *}$ & $0.25^{* *}$ & $-0.63 * *$ & & \multirow{5}{*}{ Female } & $\mathrm{q} 05$ & $-1.64 \% * * *$ & $0.87^{* * *}$ & -0.06 & 0.12 & -0.12 \\
\hline & & $\mathrm{q} 25$ & $-0.97 \% * * *$ & $1.01^{* * *}$ & $0.33^{* * *}$ & $0.17^{*}$ & 0.04 & & & $\mathrm{q} 25$ & $-0.64 \% * * *$ & $0.91^{* * *}$ & -0.12 & 0.00 & -0.24 \\
\hline & & q50 & $-0.14 \%$ & $0.92 * * *$ & $0.37^{* * *}$ & $0.27^{* * *}$ & -0.05 & & & $\mathrm{q} 50$ & $0.04 \%$ & $0.86^{* * *}$ & -0.03 & -0.04 & -0.26 \\
\hline & & $\mathrm{q} 75$ & $0.50 \% * * *$ & $0.92^{* * *}$ & $0.38^{* * *}$ & 0.23 & 0.04 & & & $\mathrm{q} 75$ & $0.65 \% * * *$ & $0.89 * * *$ & $-0.14^{* *}$ & -0.06 & -0.10 \\
\hline & & q95 & $1.48 \% * * *$ & $0.90^{* * *}$ & $0.41^{* * *}$ & 0.19 & -0.25 & & & q95 & $1.61 \%^{* * *}$ & $0.96 * * *$ & -0.15 & 0.01 & 0.04 \\
\hline \multirow{9}{*}{$\begin{array}{l}\text { Europe Large-Cap } \\
\text { Blend }\end{array}$} & \multirow{4}{*}{ Male } & $\mathrm{q} 05$ & $-0.83 \% * * *$ & $0.99 * * *$ & 0.09 & -0.02 & -0.29 & \multirow{9}{*}{$\begin{array}{l}\text { Germany } \\
\text { Large-Cap }\end{array}$} & \multirow{4}{*}{ Male } & $\mathrm{q} 05$ & $-2.38 \% * * *$ & $1.04^{* * *}$ & $0.63^{* * *}$ & -0.04 & 0.20 \\
\hline & & q50 & $0.03 \%$ & $0.98^{* * *}$ & 0.04 & -0.08 & -0.13 & & & $\mathrm{q} 50$ & $-0.11 \%$ & $0.98^{* * *}$ & $0.29 * * *$ & 0.03 & 0.37 \\
\hline & & $q 75$ & $0.54 \% * * *$ & $0.94^{* * *}$ & $0.11^{* * *}$ & -0.03 & -0.06 & & & $q 75$ & $0.57 \% * * *$ & $1.03^{* * *}$ & $0.26^{* * *}$ & -0.06 & 0.32 \\
\hline & & q95 & $1.09 \% * * *$ & $0.96^{* * *}$ & $0.14^{*}$ & -0.04 & 0.44 & & & q95 & $1.82 \% * * *$ & $1.05^{* * *}$ & 0.15 & -0.17 & $1.29 * * *$ \\
\hline & \multirow{5}{*}{ Female } & q05 & $-1.87 \% * * *$ & $1.15^{* * *}$ & 0.11 & $-0.47^{* *}$ & -0.04 & & \multirow{5}{*}{ Female } & $\mathrm{q} 05$ & - & - & - & - & - \\
\hline & & $\mathrm{q} 25$ & $-0.47 \% * * *$ & $0.95^{* * *}$ & $0.16^{* *}$ & -0.09 & $-0.34 *$ & & & $\mathrm{q} 25$ & - & - & - & - & - \\
\hline & & q50 & $0.14 \%$ & $0.91^{* * *}$ & $0.10^{*}$ & $-0.16 *$ & -0.09 & & & q50 & - & - & - & - & - \\
\hline & & $q 75$ & $0.73 \%^{* * *}$ & $0.89 * * *$ & 0.09 & -0.14 & -0.16 & & & $q 75$ & - & - & - & - & - \\
\hline & & q95 & $1.56 \% * * *$ & $0.83^{* * *}$ & 0.01 & $-0.20 *$ & -0.08 & & & q95 & - & - & - & - & - \\
\hline \multirow{2}{*}{$\begin{array}{l}\text { France Large-Cap } \\
\text { Blend }\end{array}$} & \multirow{2}{*}{ Male } & q05 & $-0.91 \% * * *$ & $0.99 * * *$ & $0.19 * * *$ & -0.04 & 0.03 & \multirow{2}{*}{$\begin{array}{l}\text { Germany } \\
\text { Small/Mid-Cap }\end{array}$} & \multirow{2}{*}{ Male } & $\mathrm{q} 05$ & $-3.46 \% * * *$ & $0.93^{* * *}$ & $-0.25 *$ & 0.24 & 0.03 \\
\hline & & $\mathrm{q} 25$ & $-0.19 \% * *$ & $0.91^{* * *}$ & $0.19^{* * *}$ & -0.04 & -0.03 & & & $\mathrm{q} 25$ & $-1.16 \% * * *$ & $0.97^{* * *}$ & $-0.43^{* *}$ & 0.14 & -0.32 \\
\hline
\end{tabular}




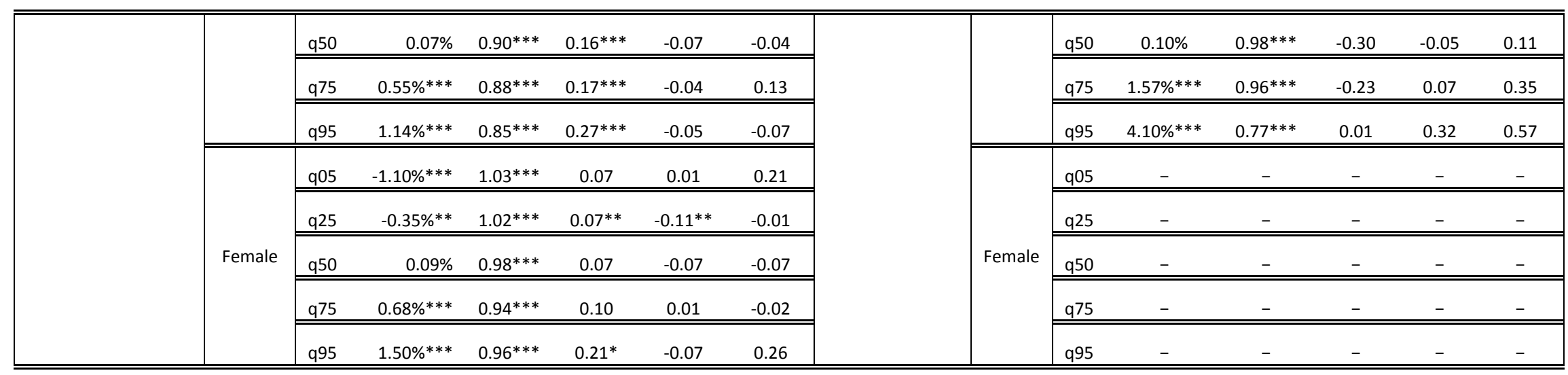

\begin{tabular}{|c|c|c|c|c|c|c|c|c|c|c|c|c|c|c|c|}
\hline & & & Intercept & $\beta_{p, 1}$ & $\beta_{p, 2}$ & $\beta_{p, 3}$ & $\beta_{p, 4}$ & & & & Intercept & $\beta_{p, 1}$ & $\beta_{p, 2}$ & $\beta_{p, 3}$ & $\beta_{\mathrm{p}, 4}$ \\
\hline \multirow{2}{*}{ Italy Equity } & \multirow{2}{*}{ Male } & $\mathrm{q} 05$ & $-1.13 \% * * *$ & $0.98^{* * *}$ & 0.16 & -0.12 & -0.17 & \multirow{2}{*}{$\begin{array}{l}\text { Spain } \\
\text { Equity }\end{array}$} & \multirow{2}{*}{ Male } & q05 & $-1.29 \% * *$ & $0.84^{* * *}$ & 0.24 & 0.10 & -0.31 \\
\hline & & $\mathrm{q} 25$ & $-0.33 \% * * *$ & $0.92^{* * *}$ & $0.20 * *$ & -0.10 & -0.11 & & & $\mathrm{q} 25$ & $-0.25 \%$ & $0.84^{* * *}$ & $0.25^{* * *}$ & -0.02 & -0.16 \\
\hline
\end{tabular}




\begin{tabular}{|c|c|c|c|c|c|c|}
\hline & q50 & $0.25 \% *$ & $0.90 * * *$ & $0.20 * * *$ & -0.06 & $-0.24 *$ \\
\hline & q75 & $0.84 \% * * *$ & $0.89 * * *$ & $0.13^{*}$ & -0.04 & $-0.39 * *$ \\
\hline & q95 & $1.55 \% * *$ & $0.96 * * *$ & 0.12 & -0.24 & -0.47 \\
\hline \multirow{5}{*}{ Female } & q05 & $-1.20 \% * * *$ & $0.96 * * *$ & $0.33^{* * *}$ & -0.09 & $-0.38^{* *}$ \\
\hline & $\mathrm{q} 25$ & $-0.46 \% * * *$ & $0.97^{* * *}$ & $0.23^{* * *}$ & $-0.15^{* * *}$ & -0.08 \\
\hline & $\mathrm{q} 50$ & $0.15 \%$ & $0.93 * * *$ & $0.19 * *$ & -0.10 & -0.20 \\
\hline & q75 & $0.88 \% * * *$ & $0.94 * * *$ & $0.17^{* *}$ & -0.10 & -0.32 \\
\hline & q95 & $2.20 \% * * *$ & $1.05^{* * *}$ & $0.15^{* * *}$ & $-0.45^{* *}$ & $-0.73 * *$ \\
\hline
\end{tabular}

\begin{tabular}{|c|c|c|c|c|c|c|}
\hline & q50 & $0.22 \%^{* *}$ & $0.82^{* * *}$ & $0.29 * * *$ & 0.03 & -0.18 \\
\hline & $q 75$ & $0.91 \% * * *$ & $0.88^{* * *}$ & $0.29 * * *$ & -0.02 & $-0.42^{* * *}$ \\
\hline & q95 & $1.99 \% * * *$ & $0.84^{* * *}$ & 0.03 & 0.11 & -0.20 \\
\hline \multirow{5}{*}{ Female } & q05 & $2.62 \% * * *$ & $0.93 * * *$ & $0.30^{*}$ & -0.19 & -0.68 \\
\hline & $\mathrm{q} 25$ & $1.12 \% * * *$ & $0.82^{* * *}$ & $0.52^{* * *}$ & -0.19 & $-0.49 *$ \\
\hline & q50 & $0.02 \%$ & $0.85^{* * *}$ & $0.49 * * *$ & -0.11 & $-0.40 * *$ \\
\hline & q75 & $0.95 \% * * *$ & $0.85^{* * *}$ & $0.56^{* * *}$ & -0.10 & -0.30 \\
\hline & q95 & $2.22 \% * * *$ & $0.92^{* * *}$ & $0.62^{* * *}$ & -0.19 & $-0.55 * * *$ \\
\hline
\end{tabular}

Note: This table reports the estimations of the multi factor performance evaluation model in Eq. (2) under the quantile regression method for the two equally-weighted portfolios of male and female managed funds. Results are presented for five different quantiles namely q05,q25,q50,q75 and q95. * , ** and *** respectively denote statistical significance at the $10 \%, 5 \%$ and $1 \%$ levels. 
Table 14

Market timing model:Quantile regression

\begin{tabular}{|c|c|c|c|c|c|c|c|c|c|c|c|}
\hline & & & Intercept & $\beta_{p}$ & $c_{p}$ & & & & Intercept & $\beta_{p}$ & $c_{p}$ \\
\hline \multirow{10}{*}{$\begin{array}{l}\text { Eurozone Small- } \\
\text { Cap }\end{array}$} & \multirow{5}{*}{ Male } & $\mathrm{q} 05$ & $-3.30 \% * * *$ & $0.72^{* * *}$ & -0.90 & \multirow{10}{*}{ Europe Small-Cap } & \multirow{5}{*}{ Male } & q05 & $-3.08 \% * * *$ & $0.80^{* * *}$ & -0.87 \\
\hline & & $\mathrm{q} 25$ & $-1.34 \% * * *$ & $0.57^{* * *}$ & -0.14 & & & $\mathrm{q} 25$ & $-1.47 \% * * *$ & $0.81^{* * *}$ & $-1.03 *$ \\
\hline & & $\mathrm{q} 50$ & $-0.05 \%$ & $0.58^{* * *}$ & -0.09 & & & q50 & $0.01 \%$ & $0.74 * * *$ & -1.01 \\
\hline & & $q 75$ & $1.59 \% * *$ & $0.52^{* * *}$ & -0.53 & & & $q 75$ & $1.17 \%^{* * *}$ & $0.70^{* * *}$ & $-0.88^{* *}$ \\
\hline & & q95 & $3.12 \% * * *$ & $0.54^{* * *}$ & -0.11 & & & q95 & $3.85 \% * * *$ & $0.69^{* * *}$ & $-1.58^{*}$ \\
\hline & \multirow{5}{*}{ Female } & q05 & $-3.61 \% * * *$ & $0.64 * * *$ & $-2.44 * *$ & & \multirow{5}{*}{ Female } & q05 & - & - & - \\
\hline & & $\mathrm{q} 25$ & $-1.29 \% *$ & $0.59^{* * *}$ & 0.01 & & & $\mathrm{q} 25$ & - & - & - \\
\hline & & $\mathrm{q} 50$ & $0.72 \%$ & $0.55^{* * *}$ & -0.39 & & & q50 & - & - & - \\
\hline & & $q 75$ & $2.10 \% * * *$ & $0.56^{* * *}$ & -0.50 & & & q75 & - & - & - \\
\hline & & q95 & $4.08 \% * * *$ & $0.50^{* * *}$ & -0.72 & & & q95 & - & - & - \\
\hline \multirow{8}{*}{$\begin{array}{l}\text { Eurozone Mid- } \\
\text { Cap }\end{array}$} & \multirow{5}{*}{ Male } & $\mathrm{q} 05$ & $-1.54 \% * * *$ & $0.94^{* * *}$ & -0.02 & \multirow{8}{*}{ Europe Mid-Cap } & \multirow{5}{*}{ Male } & q05 & $-2.12 \% * * *$ & $1.02^{* * *}$ & 0.00 \\
\hline & & $\mathrm{q} 25$ & $-0.42 \% * *$ & $0.88^{* * *}$ & -0.04 & & & $\mathrm{q} 25$ & $-0.72 \% * *$ & $0.90^{* * *}$ & -0.16 \\
\hline & & $\mathrm{q} 50$ & $0.35 \%$ & $0.87^{* * *}$ & -0.26 & & & q50 & $-0.06 \%$ & $0.96^{* * *}$ & -0.08 \\
\hline & & $\mathrm{q} 75$ & $1.16 \% * * *$ & $0.83^{* * *}$ & -0.29 & & & q75 & $0.91 \%^{* *}$ & $0.99 * * *$ & -0.04 \\
\hline & & q95 & $1.90 \% * * *$ & $0.84^{* * *}$ & 1.44 & & & q95 & $2.23 \% * * *$ & $0.97^{* * *}$ & -0.32 \\
\hline & \multirow{3}{*}{ Female } & q05 & - & - & - & & \multirow{3}{*}{ Female } & q05 & $-1.26 \% * * *$ & $1.02^{* * *}$ & $-1.21 * *$ \\
\hline & & $\mathrm{q} 25$ & - & - & - & & & $\mathrm{q} 25$ & $-0.23 \%$ & $0.97^{* * *}$ & -0.48 \\
\hline & & q50 & - & - & - & & & q50 & $0.47 \%^{* *}$ & $0.92^{* * *}$ & -0.44 \\
\hline
\end{tabular}




\begin{tabular}{|c|c|c|c|c|c|c|c|c|c|c|c|}
\hline & & q75 & - & - & - & & & $\mathrm{q} 75$ & $0.94 \% * * *$ & $0.93^{* * *}$ & $-0.40 * *$ \\
\hline & & q95 & - & - & - & & & q95 & $2.61 \% * * *$ & $0.93^{* * *}$ & -0.87 \\
\hline \multirow{10}{*}{$\begin{array}{l}\text { Eurozone Large- } \\
\text { Cap }\end{array}$} & \multirow{5}{*}{ Male } & q05 & $-0.57 \% * *$ & $0.91^{* * *}$ & -0.24 & \multirow{10}{*}{$\begin{array}{l}\text { Europe Large-Cap } \\
\text { Value }\end{array}$} & \multirow{5}{*}{ Male } & q05 & $-0.68 \%$ & $0.79 * * *$ & $-1.24 *$ \\
\hline & & $\mathrm{q} 25$ & $-0.09 \%$ & $0.93^{* * *}$ & $-0.32^{* *}$ & & & $\mathrm{q} 25$ & $0.04 \%$ & $0.83^{* * *}$ & $-1.05^{* *}$ \\
\hline & & q50 & $0.18 \% * * *$ & $0.94^{* * *}$ & $-0.22^{*}$ & & & q50 & $0.39 \% * * *$ & $0.87^{* * *}$ & $-0.83^{* *}$ \\
\hline & & $\mathrm{q} 75$ & $0.46 \% * * *$ & $0.92^{* * *}$ & -0.19 & & & $\mathrm{q} 75$ & $0.99 \% * * *$ & $0.80^{* * *}$ & -0.62 \\
\hline & & q95 & $1.42 \% * * *$ & $0.86^{* * *}$ & -0.22 & & & q95 & $2.06 \% * * *$ & $0.85^{* * *}$ & -0.98 \\
\hline & \multirow{5}{*}{ Female } & $\mathrm{q} 05$ & $-0.68 \% * * *$ & $0.88^{* * *}$ & $-0.53^{* *}$ & & \multirow{5}{*}{ Female } & q05 & $-1.26 \% *$ & $0.75^{* * *}$ & -1.30 \\
\hline & & $\mathrm{q} 25$ & $-0.12 \%$ & $0.90 * * *$ & $\begin{array}{c}- \\
0.52^{* * *} \\
\end{array}$ & & & $\mathrm{q} 25$ & $0.03 \%$ & $0.79 * * *$ & $\begin{array}{c}- \\
1.15^{* * *} \\
\end{array}$ \\
\hline & & $\mathrm{q} 50$ & $0.16 \%$ & $0.91^{* * *}$ & -0.26 & & & q50 & $0.62 \% * * *$ & $0.81^{* * *}$ & $-1.16^{* *}$ \\
\hline & & $\mathrm{q} 75$ & $0.70 \% * * *$ & $0.87^{* * *}$ & -0.24 & & & $\mathrm{q} 75$ & $1.25 \% * * *$ & $0.78^{* * *}$ & -1.18 \\
\hline & & q95 & $1.76 \% * * *$ & $0.88^{* * *}$ & -0.89 & & & q95 & $2.45 \% * * *$ & $0.73^{* * *}$ & -0.76 \\
\hline
\end{tabular}

\begin{tabular}{|c|c|c|c|c|c|c|c|c|c|c|c|}
\hline & & & Intercept & $\beta_{p}$ & $c_{p}$ & & & & Intercept & $\beta_{p}$ & $c_{p}$ \\
\hline \multirow{4}{*}{$\begin{array}{l}\text { Europe Large-Cap } \\
\text { Growth }\end{array}$} & & $\mathrm{q} 05$ & $-3.36 \% * * *$ & $1.05^{* * *}$ & -0.43 & \multirow{4}{*}{$\begin{array}{l}\text { France Small/Mid- } \\
\text { Cap }\end{array}$} & & q05 & $-1.82 \% * * *$ & $0.90^{* * *}$ & -0.74 \\
\hline & & $\mathrm{q} 25$ & $-1.46 \% * * *$ & $1.02^{* * *}$ & -0.37 & & & $\mathrm{q} 25$ & $-0.41 \%$ & $0.82^{* * *}$ & -1.17 \\
\hline & \multirow[b]{2}{*}{ Male } & q50 & $-0.25 \%$ & $1.01^{* * *}$ & -1.40 & & \multirow{2}{*}{ Male } & q50 & $0.07 \%$ & $0.80^{* * *}$ & -0.33 \\
\hline & & q75 & $1.38 \% * * *$ & $0.88^{* * *}$ & -2.38 & & & q75 & $0.70 \% * * *$ & $0.77^{* * *}$ & -0.39 \\
\hline
\end{tabular}




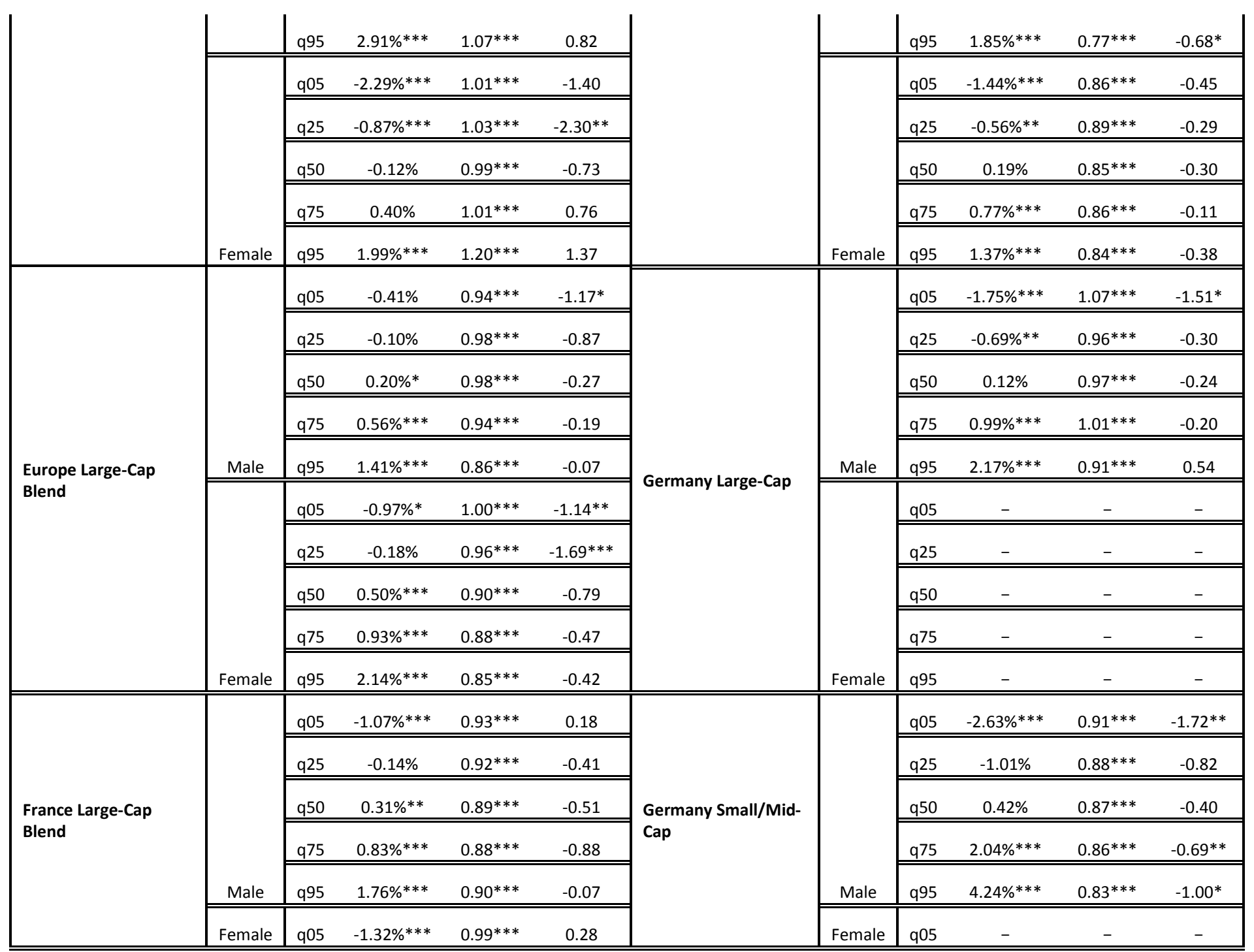




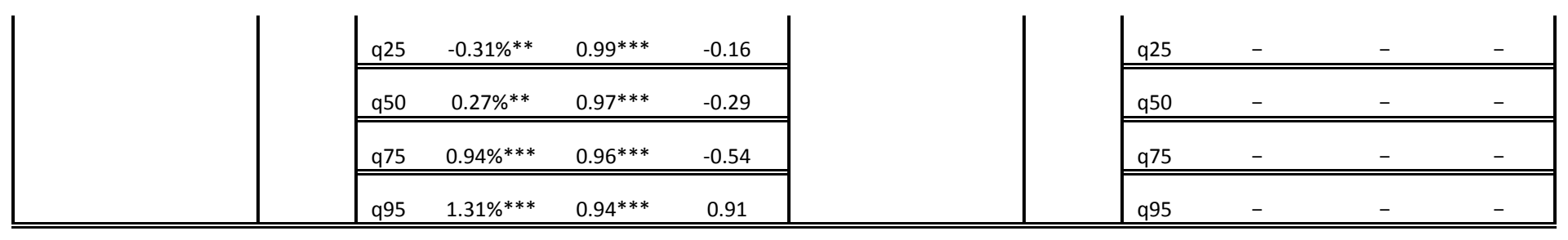

\begin{tabular}{|c|c|c|c|c|c|c|c|c|c|c|c|}
\hline & & & Intercept & $\beta_{p}$ & $c_{p}$ & & & & Intercept & $\beta_{p}$ & $c_{p}$ \\
\hline \multirow{10}{*}{$\begin{array}{l}\text { Italy } \\
\text { Equity }\end{array}$} & \multirow[b]{5}{*}{ Male } & q05 & $-0.86 \%$ & $0.88^{* * *}$ & -0.83 & \multirow{10}{*}{$\begin{array}{l}\text { Spain } \\
\text { Equity }\end{array}$} & \multirow[b]{5}{*}{ Male } & q05 & $-1.45 \% * *$ & $0.86^{* * *}$ & 0.21 \\
\hline & & $\mathrm{q} 25$ & $-0.19 \%$ & $0.86^{* * *}$ & $-0.71^{*}$ & & & $\mathrm{q} 25$ & $-0.36 \%$ & $0.86^{* * *}$ & -0.16 \\
\hline & & q50 & $0.46 \% * * *$ & $0.87^{* * *}$ & -0.54 & & & q50 & $0.56 \% * * *$ & $0.84 * * *$ & -0.45 \\
\hline & & q75 & $1.10 \% * * *$ & $0.89^{* * *}$ & -0.07 & & & q75 & $1.01 \% * * *$ & $0.83^{* * *}$ & 0.05 \\
\hline & & q95 & $2.19 \% * * *$ & $0.92 * * *$ & -0.51 & & & q95 & $2.21 \% * * *$ & $0.85^{* * *}$ & -0.29 \\
\hline & \multirow[b]{5}{*}{ Female } & $\mathrm{q} 05$ & $-1.25 \% * * *$ & $0.89 * * *$ & $-0.59^{*}$ & & \multirow[b]{5}{*}{ Female } & $\mathrm{q} 05$ & $-3.80 \% * * *$ & $1.12^{* * *}$ & -1.50 \\
\hline & & $\mathrm{q} 25$ & $-0.19 \%$ & $0.92 * * *$ & -0.77 & & & $\mathrm{q} 25$ & $-0.98 \% * *$ & $0.84 * * *$ & -0.31 \\
\hline & & q50 & $0.49 \% *$ & $0.93^{* * *}$ & -0.18 & & & q50 & $0.55 \% * *$ & $0.84^{* * *}$ & -0.57 \\
\hline & & q75 & $1.08 \% * * *$ & $0.92^{* * *}$ & -0.21 & & & q75 & $1.42 \% * * *$ & $0.76^{* * *}$ & -0.38 \\
\hline & & q95 & $2.21 \% * * *$ & $0.91 * * *$ & -0.46 & & & q95 & $3.26 \% * * *$ & $0.74 * * *$ & -0.54 \\
\hline
\end{tabular}

Note: This table reports the estimations of the Treynor \& Mazuy (1966) market timing model in Eq. (2) under the quantile regression method for the two equally-weighted portfolios of male and female managed equity funds. Results are presented for five different quantiles namely q05,q25,q50,q75 and q95. $*$, ** and $* * *$ respectively denote statistical significance at the $10 \%, 5 \%$ and $1 \%$ levels. 
